\title{
A synoptic review of Caryophyllaeus Gmelin, 1790 (Cestoda: Caryophyllidea), parasites of cyprinid fishes
}

\author{
Daniel Barčák ${ }^{1}$, Mikuláš Oros ${ }^{1}$, Vladimíra Hanzelová ${ }^{1}$ and Tomáš Scholz ${ }^{2}$ \\ ${ }^{1}$ Institute of Parasitology, Slovak Academy of Sciences, Košice, Slovak Republic; \\ ${ }^{2}$ Institute of Parasitology, Biology Centre of the Czech Academy of Sciences, České Budějovice, Czech Republic
}

\begin{abstract}
Tapeworms of the genus Caryophyllaeus Gmelin, 1790 (Caryophyllidea: Caryophyllaeidae), common parasites of cyprinid fishes, are reviewed and taxonomic status of 42 nominal taxa that have been placed in the genus during its long history is clarified. The following seven species occurring in the Palaearctic Region are recognised as valid: C. laticeps (Pallas, 1781), C. auriculatus (Kulakovskaya, 1961), C. balticus (Szidat, 1941) comb. n. (syn. Khawia baltica Szidat, 1941), C. brachycollis Janiszewska, 1953, C. fimbriceps Annenkova-Chlopina, 1919, C. syrdarjensis Skrjabin, 1913, and newly described Caryophyllaeus chondrostomi sp. n. (=C. laticeps morphotype 4 of Bazsalovicsová et al., 2014) from common nase, Chondrostoma nasus (Linnaeus), found in Austria and Slovakia. The new species differs by the paramuscular or cortical position of preovarian vitelline follicles, a large, robust body (up to $64 \mathrm{~mm}$ long), conspicuously long vas deferens, flabellate scolex with small wrinkles on the anterior margin, and anteriormost testes located in a relatively short distance from the anterior extremity. Caryophyllaeus kashmirenses Mehra, 1930 and Caryophyllaeus prussicus (Szidat, 1937) comb. n. are considered to be species inquirendae, C. truncatus von Siebold in Baird, 1853 and C. tuba von Siebold in Baird, 1853 are nomina nuda. Data on the morphology, host spectra, distribution and known life-cycles of valid species are provided. Phylogenetic interrelations of four species of the genus including its type species and newly described C. chondrostomi were assessed based on an analysis of sequences of $l s r$ DNA and coxl. A key to identification of all valid species of Caryophyllaeus is also provided.
\end{abstract}

Keywords: tapeworms, freshwater fish, Cyprinidae, systematics, identification key, phylogenetic relationships, Palaearctic Region

This article contains supporting information (Table S1) online at http://folia.paru.cas.cz/suppl/2017-64-027.pdf

Tapeworms of the genus Caryophyllaeus Gmelin, 1790 (Cestoda: Caryophyllidea) are among the most common intestinal parasites of cyprinid fishes in the Palaearctic Region, especially in Europe and the former USSR (Protasova et al. 1990), with the first species described (under the name Taenia laticeps) by Pallas (1781). Since that time, as many as 42 nominal taxa have been placed in the genus (see Table 1), which was erected by Gmelin (1790) to accommodate Caryophyllaeus piscium Gmelin, 1790 (syn. of T. laticeps).

Recent morphological and molecular evaluation of an extensive set of tapeworms of Caryophyllaeus from cyprinid fishes has revealed morphological polymorphism in two species, C. laticeps (Pallas, 1781) and C. brachycollis Janiszewska, 1953, and their wide (euryxenous) host specificity (Bazsalovicsová et al. 2014). In C. laticeps, five morphotypes, mostly specific to their cyprinid hosts, including common carp (Cyprinus carpio Linnaeus), common nase (Chondrostoma nasus [Linnaeus]), Macedonian vimba (Vimba melanops [Heckel]), and white-eyed bream (Ballerus sapa [Pallas]), were recognised. In C. brachy- collis, two morphotypes typical of the barbels (Barbinae) and chub (Squalius cephalus [Linnaeus]), and freshwater breams (Leuciscinae), respectively, were distinguished based on their morphology and DNA sequences (see Barčák et al. 2014, Bazsalovicsová et al. 2014, Hanzelová et al. 2015).

In the present paper, all species placed in the genus since its erection by Gmelin (1790) are surveyed on the basis of a critical review of available literature and morphological evaluation of an extensive set of specimens deposited in helminthological collections and newly found tapeworms collected by the present authors and their collaborators. The generic diagnosis of Caryophyllaeus is emended and an annotated list is provided together with an identification key of all species recognised as valid.

\section{MATERIALS AND METHODS}

The present revision is based on (i) a critical review of literary data including papers published in the 18th and 19th Centuries; (ii) taxonomic study of numerous specimens deposited in museum collections in Europe and former Soviet Union; and (iii) mor- 
phological and genetic evaluation of newly collected tapeworms (see Barčák et al. 2014, Bazsalovicsová et al. 2014, Hanzelová et al. 2015). The methodology of the morphological study, i.e. fixation and processing of newly collected specimens, including evaluation using light and scanning electron (SEM) microscopy, has been described in previous papers by the present authors (Oros et al. 2010, Scholz et al. 2011, Barčák et al. 2014, Hanzelová et al. 2015). Extensive molecular data on Caryophyllaeus brachycollis and C. laticeps were provided by Bazsalovicsová et al. (2014). In morphological descriptions, measurements are in millimetres (mm) unless otherwise indicated; terminology of microtriches follows Chervy (2009). The scientific and common names of fish hosts are from FishBase (Froese and Pauly 2016).

The specimens studied were deposited in the following helminthological collections: The Natural History Museum, London, UK (BMNH); the former Helminthological Laboratory of the Russian Academy of Sciences, Moscow, Russia (GELAN); Institute of Parasitology, Biology Centre of the Czech Academy of Sciences, České Budějovice, Czech Republic (IPCAS); Institute of Parasitology, SAS, Košice, Slovakia (IPSAS); Natural History Museum, Geneva, Switzerland (MHNG-PLAT); Department of Invertebrate Zoology, National Museum of Natural History, Smithsonian Institution, Washington, D.C., USA (USNM); Schmalhausen Institute of Zoology of the Ukrainian Academy of Sciences, Kiev, Ukraine (ZIK); and Zoological Institute of the Russian Academy of Sciences, St. Petersburg, Russia (ZIRAS).

Molecular analysis was performed on the newly collected tapeworms from Cyprinus carpio obtained by park staff from a pond in the Parco Regionale del Delta del Po (Ferrara Province), Italy. After rinsing in saline solution and preservation in 99\% ethanol, middle body parts were used for DNA isolation using DNeasy ${ }^{\circledR}$ Blood \& Tissue Kit (QIAGEN, Hilden, Germany). For PCR amplification, LSU5 and 1500R primers (Littlewood et al. 2000, Olson et al. 2003) were used for partial large subunit nuclear ribosomal RNA (D1-D3 domains of $l s r$ DNA, 1,578 bp), while CFCYT2 and CRCYT2 primers (Bazsalovicsová et al. 2011) were used for partial mitochondrial gene cytochrome c oxidase subunit I ( $\operatorname{cox} 1,657 \mathrm{bp}$ ). PCR products were enzymatically purified with exonuclease I and alkaline phosphatase (Werle et al. 1994) and directly sequenced at GATC Biotech (Cologne, Germany). PCR products were sequenced using both amplification primers, while internal primers $900 \mathrm{~F}$ and 400R (Olson et al. 2003) were additionally used in the case of $l s r$ DNA.

Phylogenetic analysis was performed on a concatenated dataset of the tapeworms newly found in Italy and sequences available in GenBank ${ }^{\mathrm{TM}}$ (Table S1). Contiguous gene sequences were assembled and aligned using Geneious ver. 9.1.6 (http://www. geneious.com; Kearse et al. 2012); individual gene alignments were built with E-INS-i algorithm of MAFFT (Katoh and Standley 2013). Phylogenetic relationships were estimated under maximum likelihood criterion in RAxML 7.2.8 program (Stamatakis 2006) implemented in Geneious employing GTR + I + G model, which was determined with PartitionFinder ver 1.1.1. (Lanfear et al. 2012). Bootstrap nodal support values (1,000 replicates) were also estimated in RAxML.

\section{RESULTS}

\section{Species composition of the genus}

The following seven species of Caryophyllaeus, rather than the 42 nominal taxa from the Palaearctic, Nearctic, Afrotropical (Ethiopian) and Indomalayan (Oriental) zoogeographical regions, placed in the genus during more than 200 years since its erection by Gmelin (1790), are recognised as valid (Table 1; species are listed alphabetically except for the type species, which appears first): Caryophyllaeus laticeps (type species); C. auriculatus (Kulakovskaya, 1961); C. balticus (Szidat, 1941) comb. n. (syn. Khawia baltica Szidat, 1941); C. brachycollis; C. fimbriceps Annenkova-Chlopina, 1919; C. syrdarjensis Skrjabin, 1913; and a new species, $C$. chondrostomi, from Chondrostoma nasus described below. An annotated list of valid species of Caryophyllaeus with data on their fish hosts, geographical distribution and life-cycles (if known) is provided below together with an amended diagnosis of the genus that reflects, among others, new inclusion of $C$. balticus which possesses cortical vitelline follicles, thus having been previously placed in the genus Khawia Hsü, 1935 of the family Lytocestidae Hunter, 1927. Caryophyllaeus kashmirenses Mehra, 1930 and Caryophyllaeus prussicus (Szidat, 1937) comb. n. are considered to be species inquirendae.

\section{Amended diagnosis of Caryophyllaeus Gmelin, 1790}

Syns.: Chariophyllus Bloch, 1782; Caryophyllinus Schrank, 1788

Diagnosis. Caryophyllidea, Caryophyllaeidae, with characters of family except for vitelline follicles being both medullary and/or cortical. Scolex dorsoventrally flattened, lacking apical structures and lateral loculi (afossate), variable in shape. Testes numerous, reaching posteriorly to cirrus-sac. Internal seminal vesicle may be present; external seminal vesicle absent. Ovary follicular, H-shaped. Seminal receptacle present. Vagina joins with uterus to form common uterovaginal duct. Vitelline follicles usually medullary, rarely both medullary and cortical, or exclusively cortical, extensive, separated into preovarian and postovarian groups of follicles; follicles may be present alongside preovarian loops of uterus, exceptionally few follicles lateral to ovarian arms. Uterus never extends anterior to cirrus-sac; uterine region usually short in relation to body length. Uterine glands present. Male and female genital pores separated, opening close to each other on ventral side of body. Parasites of cyprinid fishes (Cypriniformes: Cyprinidae) in the Palaearctic Region (Europe, northern Africa, Palaearctic Asia).

Ty p e species: Caryophyllaeus piscium Gmelin, 1790 (syn. Caryophyllaeus laticeps [Pallas, 1781] Lühe, 1910).

Remarks. The genus was erected by Gmelin (1790) to accommodate Caryophyllaeus piscium. Numerous authors 
Table 1. List of species placed in Caryophyllaeus Gmelin, 1790 and their current taxonomic status. Species of the genus recognised herein as valid in bold.

\begin{tabular}{|c|c|c|c|}
\hline Species name & Current taxonomic status or valid name & Region* & Remarks \\
\hline acutus Bovien, 1926 & $\begin{array}{l}\text { Syn. of Lucknowia microcephala (Bovien, 1926) } \\
\text { Ash, Scholz, Oros et Kar, } 2011\end{array}$ & IND & $\begin{array}{l}\text { Lucknowia microcephala redescribed by Ash et al. } \\
\text { (2011a) }\end{array}$ \\
\hline appendiculatus Ratzel, 1868 & $\begin{array}{l}\text { Syyn. of C. mutabilis ( }=\text { C. laticeps }) \text { according to } \\
\text { Srámek }(1901 ; \text { p. 114) }\end{array}$ & PAL & $\begin{array}{l}\text { Described from larvae (metacestodes) without eggs, } \\
\text { i.e. not progenetic; they may belong to any species } \\
\text { occurring in Europe }\end{array}$ \\
\hline armeniacus Cholodkovsky, 1915 & $\begin{array}{l}\text { Khawia armeniaca (Cholodkovsky, 1915) } \\
\text { Shulman, } 1958\end{array}$ & $\begin{array}{l}\text { PAL, } \\
\text { ETH (?) }\end{array}$ & Redescribed by Scholz et al. (2011a) \\
\hline $\begin{array}{l}\text { auriculatus (Kulakovskaya, 1961) } \\
\text { Scholz, Oros, Choudhury, Brabec } \\
\text { et Waeschenbach, } 2015\end{array}$ & Valid species & PAL & $\begin{array}{l}\text { Originally described in Monobothrium Diesing, } 1863 \\
\text { by Kulakovskaya (1961) }\end{array}$ \\
\hline balticus (Szidat, 1941) comb. n. & Valid species & PAL & $\begin{array}{l}\text { Originally described in Khawia Hsü, } 1935 \text { by Szidat } \\
\text { (1941) }\end{array}$ \\
\hline brachycollis Janiszewska, 1953 & Valid species & PAL & Redescribed by Barčák et al. (2014) \\
\hline $\begin{array}{l}\text { caspicus Annenkova-Chlopina, } \\
1919\end{array}$ & Syn. of Caryophyllaeus laticeps & PAL & Listed as a synonym in Protasova et al. (1990) \\
\hline $\begin{array}{l}\text { catostomi (Cooper, 1920) Wood- } \\
\text { land, } 1923\end{array}$ & Glaridacris catostomi Cooper, 1920 & NEA & $\begin{array}{l}\text { Originally described in Glaridacris Cooper, } 1920 \text { but } \\
\text { Woodland (1923) synonymised this genus with Caryo- } \\
\text { phyllaeus }\end{array}$ \\
\hline chalmersius Woodland, 1924 & $\begin{array}{l}\text { Monobothrioides chalmersius (Woodland, 1924) } \\
\text { Hunter, } 1930\end{array}$ & ETH & $\begin{array}{l}\text { Originally described in Caryophyllaeus, then placed to } \\
\text { Lytocestus Cohn, } 1908 \text { by Fuhrmann and Baer (1925) }\end{array}$ \\
\hline communis Schrank, 1788 & Syn. of Caryophyllaeus laticeps & PAL & $\begin{array}{l}\text { Described as Caryophyllinus communis Schrank, } 1788 \text {, } \\
\text { with reference to Bloch (1782) and Goeze }(1782) \text { - see } \\
\text { remark to C. piscium; syn. of C. mutabilis (= C. latice- } \\
\text { ps) according to Srámek (1901) }\end{array}$ \\
\hline cyprinorum Zeder, 1803 & Syn. of Caryophyllaeus laticeps & PAL & $\begin{array}{l}\text { Listed as a synonym of } C \text {. mutabilis }(=C \text {. laticeps }) \text { by } \\
\text { van Beneden }(1858) \text { an Śrámek }(1901)\end{array}$ \\
\hline fennicus Schneider, 1902 & $\begin{array}{l}\text { Caryophyllaeides fennica (Schneider, 1902) } \\
\text { Nybelin, } 1922\end{array}$ & PAL & Type species of Caryophyllaeides Nybelin, 1922 \\
\hline filiformis Woodland, 1923 & Lytocestus filiformis (Woodland, 1923) & ETH & To be transferred to another genus \\
\hline $\begin{array}{l}\text { fimbriceps Annenkova-Chlopina, } \\
1919\end{array}$ & Valid species & PAL & $\begin{array}{l}\text { Possibly disappeared from European waters (see } \\
\text { Remarks) }\end{array}$ \\
\hline fuhrmanni Szidat, 1937 & Syn. of Caryophyllaeus laticeps & PAL & $\begin{array}{l}\text { Treated as doubtful species (Janiszewska 1954) and } \\
\text { synonymised by Mackiewicz (1962) }\end{array}$ \\
\hline gotoi Motomura, 1927 & Paracaryophyllaeus gotoi (Motomura, 1927) & PAL & Probably a complex of species (Scholz et al. 2014) \\
\hline $\begin{array}{l}\text { hexacotyle (Linton, 1897) Wood- } \\
\text { land, } 1923\end{array}$ & $\begin{array}{l}\text { Syn. of Isoglaridacris hexacotyle (Linton, 1897) } \\
\text { Mackiewicz, } 1968\end{array}$ & NEA & $\begin{array}{l}\text { Originally described in Monobothrium but Woodland } \\
\text { (1923) synonymised this genus with Caryophyllaeus; } \\
\text { Hunter (1927) placed the species in Glaridacris }\end{array}$ \\
\hline indicus Moghe, 1925 & $\begin{array}{l}\text { Lytocestus indicus (Moghe, 1925) Woodland, } \\
1926\end{array}$ & IND & Redescribed by Ash et al. (2011a) \\
\hline japonensis Yamaguti, 1934 & Khawia japonensis (Yamaguti, 1934) Hsü, 1935 & PAL & Redescribed by Scholz et al. (2011a) \\
\hline javanicus Bovien, 1926 & Syn. of Lytocestus indicus & IND & Lytocestus indicus redescribed by Ash et al. (2011a) \\
\hline kasmirenses Mehra, 1930 & Species inquirenda & IND & $\begin{array}{l}\text { Described by Mehra (1930) from Schizothorax micro- } \\
\text { pogon Heckel, Srinagar, Kashmir in abstract only }\end{array}$ \\
\hline laruei Lamont, 1921 & Glaridacris laruei (Lamont, 1921) Hunter, 1927 & NEA & $\begin{array}{l}\text { Transferred to Glaridacris as G. laruei comb. n. by } \\
\text { Hunter (1927) }\end{array}$ \\
\hline laticeps (Pallas, 1781) Lühe, 1910 & Valid species & PAL & $\begin{array}{l}\text { Described as Taenia laticeps by Pallas (1781); type } \\
\text { species; redescribed by Hanzelová et al. (2015) }\end{array}$ \\
\hline microcephalus Bovien, 1926 & $\begin{array}{l}\text { Lucknowia microcephala (Bovien, 1926) Ash, } \\
\text { Scholz, Oros et Kar, } 2011\end{array}$ & IND & Redescribed by Ash et al. (2011a) \\
\hline minutus Chen, 1973 & $\begin{array}{l}\text { Syn. of Atractolytocestus huronensis Anthony, } \\
1958\end{array}$ & & $\begin{array}{l}\text { Erroneous generic placement, corrected in the present } \\
\text { study }\end{array}$ \\
\hline mutabilis Rudolphi, 1802 & Syn. of Caryophyllaeus laticeps & PAL & $\begin{array}{l}\text { Long time considered valid, e.g. by Baird (1853) who } \\
\text { listed T. laticeps as its senior synonym; Lühe (1910) } \\
\text { first listed } C \text {. laticeps with C. mutabilis as its synonym, } \\
\text { but in the legend to his fig. } 4 \text { wrote "C. mutabilis" }\end{array}$ \\
\hline niloticus Kulmatycki, 1928 & Syn. of Wenyonia virilis Woodland, 1923 & ETH & $\begin{array}{l}\text { Kulmatycki (1928) finished his description of C. niloti- } \\
\text { cus in May 1920, but its publication was delayed until } \\
1928 \text { due to author's eye disease; the author himself } \\
\text { admitted in a footnote on the first page of his paper that } \\
\text { his species is identical with Wenyonia virilis }\end{array}$ \\
\hline oxycephalus Bovien, 1926 & Syn. of Lytocestus indicus & IND & Lytocestus indicus redescribed by Ash et al. (2011a) \\
\hline parvus Zmeev, 1936 & $\begin{array}{l}\text { Khawia parva (Zmeev, 1936) Kulakovskaya, } \\
1961\end{array}$ & PAL & $\begin{array}{l}\text { Listed as a synonym of } C \text {. fennica by Dubinina (1962); } \\
\text { redescribed by Scholz et al. (2011a) }\end{array}$ \\
\hline piscium Gmelin, 1790 & Syn. of Caryophyllaeus laticeps & PAL & $\begin{array}{l}\text { Gmelin (1790) referred to conspecific worms reported } \\
\text { by Bloch (1782) and Goeze (1782); the former author } \\
\text { (p. 34) did not give them specific name, placing them } \\
\text { in Chariophyllus Bloch, 1782, whereas the latter author } \\
\text { (pp. 180, 181) called his worms from cyprinids as } \\
\text { Fasciola fimbriata (p. 180) but later (p. 181) considered } \\
\text { them identical with Taenia laticeps of Pallas (1781) }\end{array}$ \\
\hline prussicus (Szidat, 1937) & Species inquirenda & PAL & Possibly a synonym of $C$. laticeps \\
\hline
\end{tabular}


Table 1. Continued.

\section{Species name}

punctulatus Molin, 1858

serialis Bovien, 1926

stentoreus Schrank, 1788

syrdarjensis Skrjabin, 1913

tenuicollis Bovien, 1926 land, 1923

trisignatus Molin, 1861

truncatus von Siebold in Baird, 1853

tuba von Siebold in Baird, 1853 skrjabini Popoff, 1924

terebrans (Linton, 1893) Wood-

\section{Current taxonomic status or valid name}

Syn. Monobothrium punctulatum Diesing, 1863; PAL species insertae sedis; described from the European eel, Conger conger (Linnaeus), i.e. from a marine fish

Bovienia serialis (Bovien, 1926) Fuhrmann, 1931IND

Syn. of Caryophyllaeides fennica

Syn. of Caryophyllaeus laticeps

\section{Region* Remarks}

Not a caryophyllidean cestode (see Woodland 1923 and Scholz et al. 2015)

Redescribed by Ash et al. (2011a)

PAL Kulakovskaya (1961) first synonymised this species with $C$. fennica

PAL Described as Caryophyllinus stentoreus Schrank, 1788; description (Schrank 1788, p. 6) contains only brief description: "Der Körper walzenähnlich, trompetenförmig" (tubular, trompet-shaped)

Valid species

PAL Described from Schizothorax intermedius McClelland

Pseudocaryophyllaeus tenuicollis (Bovien, 1926) IND Ash, Scholz, Oros et Kar, 2011

Glaridacris terebrans (Linton, 1893) Mackiewicz, 1974

Species insertae sedis; larvae described from the PAL European hake, Merluccius merluccius, i.e. from a marine fish

Nomen nudum

Nomen nudum

PAL

tuba Monticelli, 1892

Monobothrium wageneri Nybelin, 1922
PAL

Redescribed by Ash et al. (2011a)

NEA Originally described in Monobothrium but Woodland (1923) synonymised this genus with Caryophyllaeus

Not a caryophyllidean; probably larvae (metacestodes) of a species of 'Tetraphyllidea', i.e. cestodes maturing in elasmobranchs

No description of worms found in Chondrostoma nasus Linnaeus was provided by von Siebold in Baird (1853)

Nybelin (1922 - p. 111) considered this species from

Salmo trutta fario Linnaeus as a synonym of Cyathocephalus truncatus (Pallas, 1781), but it was not described by von Siebold in Baird (1853) and thus it is nomen nudum

PAL Homonym of Caryophyllaeus tuba von Siebold in

Baird, 1853; a new name, Monobothrium wageneri, was proposed by Nybelin $(1922$ - p. 118)

*Zoogeographical regions: ETH - Ethiopian; IND - Indomalayan; NEA - Nearctic; PAL - Palaearctic.

(Joyeux and Baer 1936, Wardle and McLeod 1952, Janiszewska 1954, Yamaguti 1959, Dubinina 1962, Schmidt 1986) reported Müller (1787) as an authority of the genus, whereas Stiles and Hassal (1912), Nybelin (1922) and Mackiewicz $(1972,1994)$ credited the authority to Gmelin (1790). As Müller (1787) on p. 79 lists only "Nelkenwurm" (the common name for Caryophyllaeus), but not the Latin name, the authority of the genus is attributed to Gmelin (1790). Species that are currently placed in Caryophyllaeus were originally accommodated in the following genera: Fasciola Linnaeus, 1758; Taenia Linnaeus, 1758; Chariophyllus Bloch, 1782; Caryophyllinus Schrank, 1788; Phylline Abildgaard, 1793; and Khawia (see Hanzelová et al. 2015 for references).

\section{An annotated list of valid species of Caryophyllaeus Gmelin, 1790}

\section{Caryophyllaeus laticeps (Pallas, 1781) - type species}

Figs. 1, 2, 8A,B

Syns.: Taenia laticeps Pallas, 1781; Fasciola fimbriata Goeze, 1782; Caryophyllinus communis Schrank, 1788; Caryophyllinus stentoreus Schrank, 1788; Caryophyllaeus piscium Gmelin, 1790; Caryophyllaeus mutabilis Rudolphi, 1802; Caryophyllaeus appendiculatus Ratzel, 1868; Caryophyllaeus cyprinorum Zeder, 1803; Caryophyllaeus caspicus Annenkova-Chlopina, 1919; Caryophyllaeus fuhrmanni Szidat, 1937; Khawia coregoni Kritscher, 1990

Material examined. See Bazsalovicsová et al. (2014), Hanzelová et al. (2015) and Xi et al. (2016); in addition, 20 hot-formalin fixed specimens from Carassius carassius
(Linnaeus), Filo d'Argenta, Ferrara Province, Italy, collected on 20 May 2002 by B.S. Dezfuli (IPCAS C-2/11), nine specimens from Cyprinus carpio, Parco Regionale del Delta del Po near Campotto, Italy, collected on 3 May 2016 by D.B. (IPSAS IT209/16-1, IT211/16-1-IT211/16-4, IT212/16-1-IT212/16-4) and five specimens from Ballerus sapa, River Danube near Iža, Slovakia, collected on 23 April 2013 by V.H. (IPSAS SK12/13-1, SK12/13-2, SK12/13-4, SK12/13-5, SK12/13-7) were studied.

Diagnosis (compiled from Hanzelová et al. 2015, who described five morphotypes; see also Table 2). Body elongated, slender to robust, with maximum width at cirrus-sac region, narrowing towards posterior end. Scolex variable in shape, always wider, usually conspicuously, than neck and remaining body. Testes oval to almost spherical, intermingled with vitelline follicles. Anteriormost testes far from anterior extremity. Posteriorly, testes reach to anterior margin of cirrus-sac. Vas deferens well-developed, long, in distal (posterior) part not surrounded by vitelline follicles. Cirrus-sac small to moderately large, subspherical, not far from posterior end of body. Internal sperm duct enlarged to form conspicuous internal seminal vesicle (Figs. 1B, 2E,F). Ovary with symmetrical lateral lobes (anterior lobes more or less of same length as posterior lobes or anterior lobes only slightly shorter). Vagina slightly sinuous, especially in its proximal part. Seminal receptacle pyriform. Vitelline follicles medullary, exceptionally paramuscular. Preovarian vitelline follicles irregularly-shaped, numerous, distributed lateral and median, surrounding testes, absent alongside ovary. Postovarian follicles usually numerous. Uterus forms several loops between ovary and posterior part of cirrus-sac. 


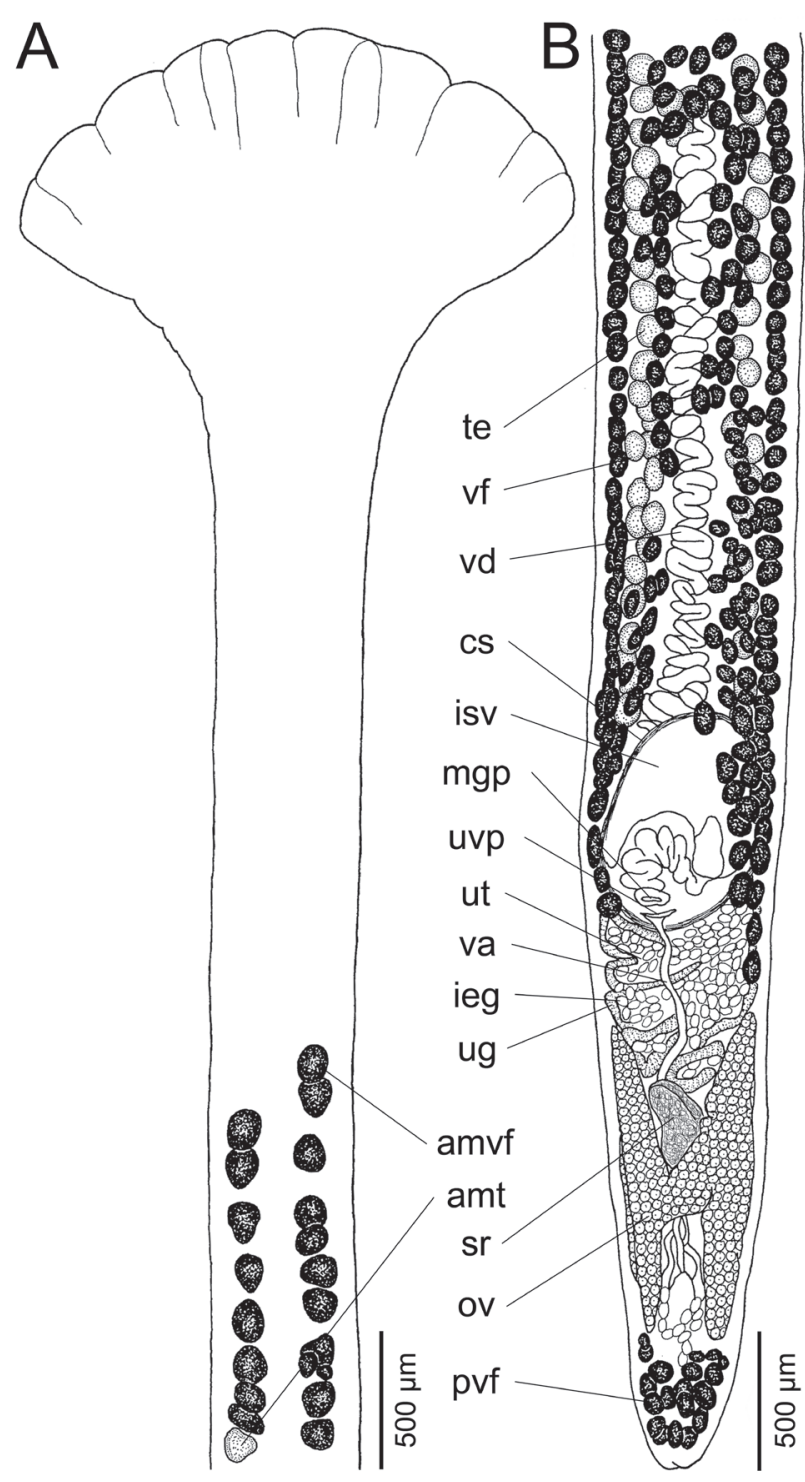

Fig. 1. Caryophyllaeus laticeps (Pallas, 1781) from Abramis brama (Linnaeus), Slovakia. A - anterior part of the body (note long distance of anteriormost testes from anterior margin of scolex); B - posterior part of body, ventral view (note vas deferens not surrounded by vitelline follicles nor testes in medial line and well-developed internal seminal vesicle). Abbreviations: amt - anteriormost testis; amvf - anteriormost vitelline follicle; cs - cirrus-sac; ieg - intrauterine eggs; isv - internal seminal vesicle; mgp - male genital pore; ov - ovary; pvf - postovarian vitelline follicles; sr - seminal receptacle; te - testes; ug - uterine glands; ut - uterus; uvp - uterovaginal pore; va - vagina; vd - vas deferens; vf - vitelline follicles.

Type host: Freshwater bream, Abramis brama (Linnaeus) (Cyprinidae: Leuciscinae).

Additional hosts: Cyprinid fishes of the subfamilies Alburninae (4 species), Barbinae (9), Cyprininae (4), Gobioninae (1), Leuciscinae (19) and Tincinae (1); however, some records require verification (see Hanzelová et al. 2015).

Type locality: Not specified by Pallas (1781).

Type specimens: Since no type specimens were deposited, Hanzelová et al. (2015) designated the specimen from Abramis brama, Cheboksary Water Reservoir on the River Volga, Russia as the neotype of C. laticeps (IPCAS C-2/1).
Sequence data. Partial coxl sequences (JQ034066JQ034068, JQ034070, JQ034071, JQ034077; Brabec et al. 2012; KF051092-KF051099, KF051102-KF051104, KF051107, KF051108, KF051114, KF051115, KF051117, KF051118, KF051126, KF051127, KF051131, KF051132; Bazsalovicsová et al. 2014), complete nad3 sequences (JQ034003-JQ034005, JQ034007, JQ034008, JQ034014; Brabec et al. 2012), partial mitochondrial genome (JQ268540; Waeschenbach et al. 2012; KT781573KT781580; Xi et al. 2016), cox1 pseudogene (JQ034065, JQ034069, JQ034072-JQ034076; Brabec et al. 2012), nad3 pseudogene (JQ034002, JQ034006, JQ034009JQ034013; Brabec et al. 2012), partial lsrDNA sequences (AF286911; Olson et al. 2001; AY157180; Lockyer et al. 2003; JQ034121-JQ034123; Brabec et al. 2012; KF051141-KF051153, KF051159-KF051163, KF051169, KF051173, KF051176, KF051177; Bazsalovicsová et al. 2014), partial ssrDNA sequences (Z98308-10; Mariaux 1998; AJ287488; Littlewood and Olson 2001; JQ034138JQ034140; Brabec et al. 2012), complete ITS2 sequences (KF700250-KF700252; Králová-Hromadová et al. 2013), microsatellite C53 sequences (KM267645-KM267650; Králová-Hromadová et al. 2015).

Life cycle. Limnodrilus claparedeanus Ratzel, Psammoryctides barbatus (Grube) and Tubifex tubifex (Müller) (Naididae: Tubificinae) have been reported as natural or experimental intermediate hosts of $C$. laticeps (see Mrázek 1901, Sekutowicz 1934, Kennedy 1969, Davydov and Poddubnaya 1988, Protasova et al. 1990, Poddubnaya 1995). However, some metacestode stages found in naturally infected hosts may have been misidentified, such as some of the young stages in the intestine photographed by Sekutowicz (1934), which resemble Morphotype 2 of C. brachycollis. Milbrink (1975), referring to a paper by Timm (1972), reported four species of Potamothrix Vejdovský et Mrázek, namely P. bedoti (Piquet), P. hammoniensis (Michaelsen), $P$. heuscheri (Bretscher) and $P$. vejdovskyi (Hrábě), as intermediate hosts of $C$. laticeps.

Distribution. Europe (Albania, Austria, Belarus, Bulgaria, Czech Republic, Estonia, Finland, France, Germany, Hungary, Ireland, Italy, Latvia, Liechtenstein, Lithuania, Macedonia, Montenegro, Norway, Poland, Romania, Russia, Serbia, Slovakia, Spain, Sweden, Switzerland, UK including Northern Ireland and Ukraine), Palaearctic Asia (Azerbaijan, China, Georgia, Iran, Iraq, Japan, Kazakhstan, Russia, Turkey and Uzbekistan), and northern Africa (Egypt and Morocco) (Gibson 2013a; for distribution of individual morphotypes - see Hanzelová et al. 2015).

Remarks. Caryophyllaeus laticeps is a polymorphic species with several morphotypes that differ from each other in the shape and size of the body and scolex, the extent of the vitelline follicles and other morphological characteristics (Hanzelová et al. 2015); individual morphotypes also differ from each other genetically (Bazsalovicsová et al. 2014). This species can be distinguished from C. brachycollis and $C$. fimbriceps, which may occur in the same fish hosts, by the following morphological characteristics: (i) a subspherical, thin-walled cirrus-sac near the posteri- 


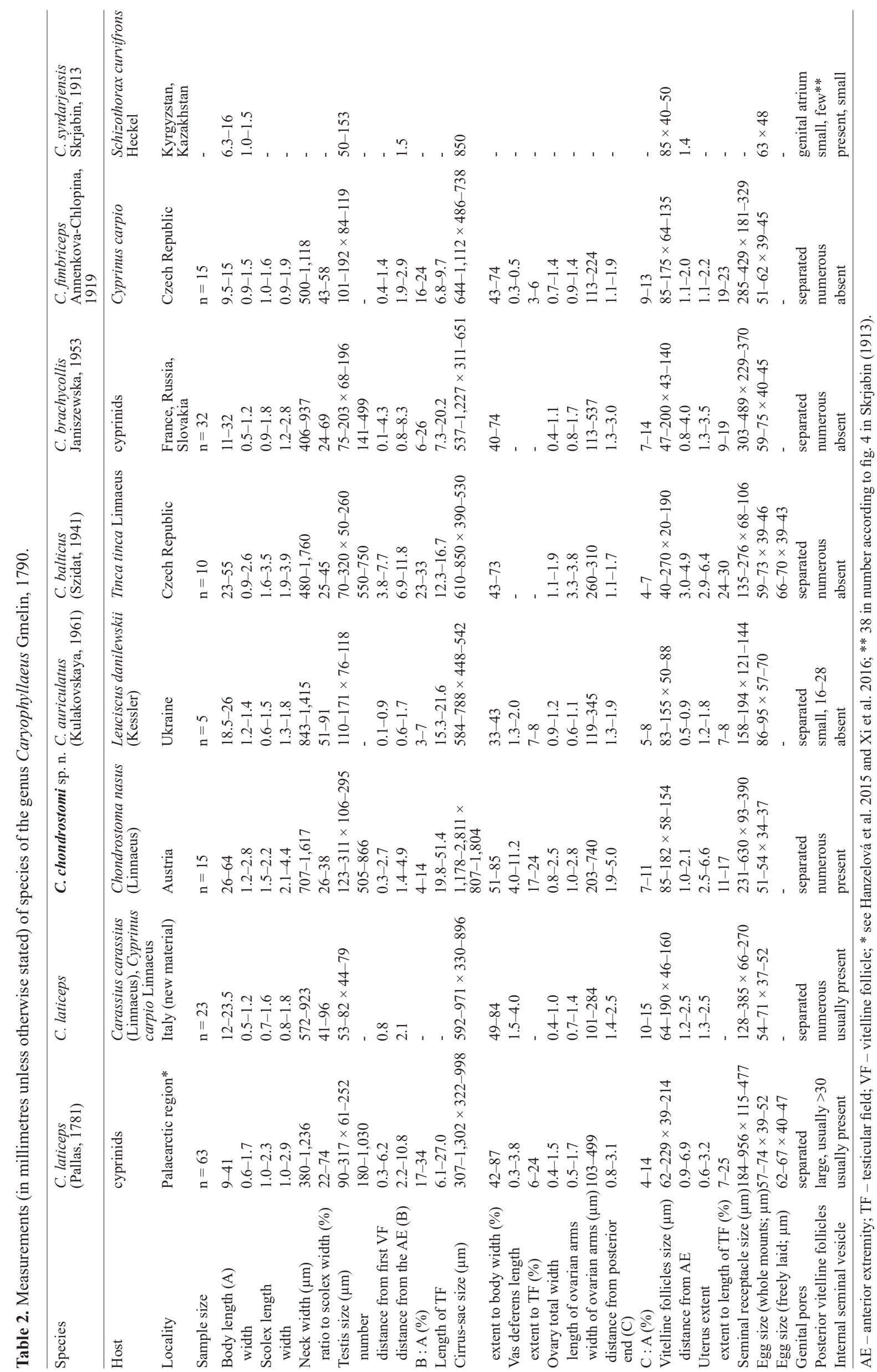




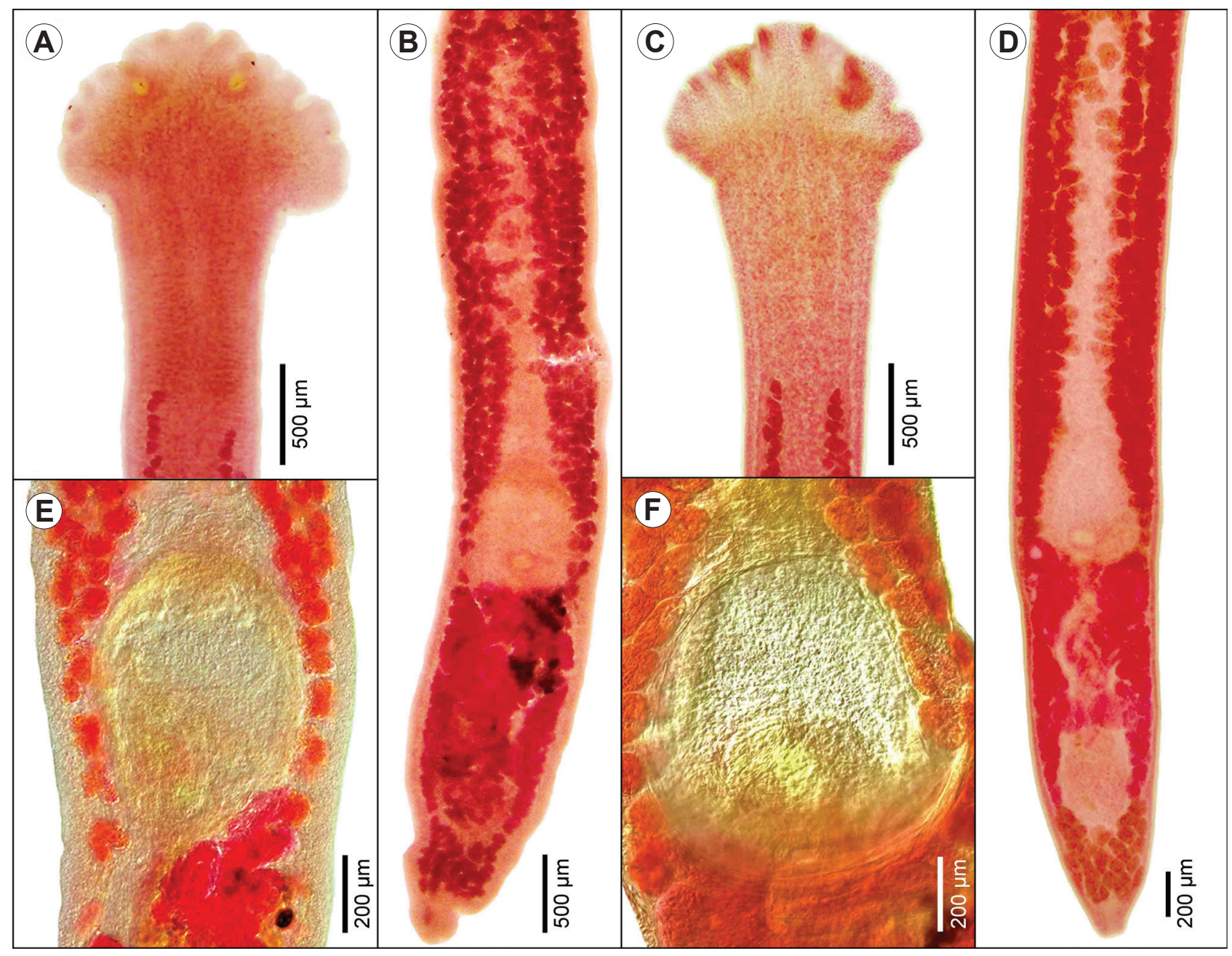

Fig. 2. Morphologically similar specimens of Caryophyllaeus laticeps (Pallas, 1781) from Carassius carassius (Linnaeus) (A, B, E) and from Cyprinus carpio Linnaeus (C, D, F) found in the neighbouring localities near Argenta, Italy. A, C - anterior part of the body; B, D - posterior part of the body, both ventral views; $\mathbf{E}, \mathbf{F}$ - cirrus-sac with a large internal seminal vesicle.

or end, containing a well-developed internal seminal vesicle ( $v s$ a large, thick-walled, strongly muscular cirrus-sac without a distinct internal seminal vesicle in $C$. brachycollis and C. fimbriceps - see fig. 2M,L in Scholz 1989 and figs. 2 and 3A,B in Barčák et al. 2014); (ii) the absence of the vitelline follicles alongside the median line of the body at the level of the distal course of the vas deferens (follicles present, i.e. circum-medullary, overlaying vas deferens in C. brachycollis and C. fimbriceps); (iii) a more posterior position of the ovary (more anterior in C. brachycollis - fig. 2 in Barčák et al. 2014); and (iv) possession of the scolex of different shape (C. fimbriceps possesses a cuneicrispitate scolex - see fig. 2D,E in Scholz 1989 and fig. 1H,I,J in Oros et al. 2010).

Comparison of tapeworms found in Carassius carassius and Cyprinus carpio from Italy (Figs. 2, 8B) with those of $C$. laticeps studied by Hanzelová et al. (2015) revealed their conspecificity, which was also confirmed by molecular data (lsrDNA and cox 1 sequences of tapeworms from C. carpio; Fig. 9). In addition, these tapeworms are in some characteristics similar to Caryophyllaeus prussicus comb. n. (syn. Bothrioscolex prussicus Szidat, 1937) (see figs. 4, 5 in Szidat 1937 and Figs. 2, 8B in the present paper). Szi- dat's (1937) worm resembles these tapeworms from Italy in the testes difficult to observe (a unique characteristic among all caryophyllideans), the shape and size of the body, a cuneicrispitate scolex wider than the body, and extensive vitelline follicles that reach anteriorly to some distance posterior to the scolex and that only partially surround the region of the vas deferens on the ventral side.

However, C. prussicus, which was described based on a single specimen, allegedly differs from the specimens recently found in Italy in its possession of a smaller cirrus-sac, as could be assumed from fig. 5 in Szidat (1937) (vs a somewhat larger cirrus-sac in Italian specimens) and by having a more posterior extent of the preovarian vitelline follicles (reaching up to the ovary in C. prussicus vs reaching only posterior to the cirrus-sac in the specimens from Italy). The species is considered as species inquiren$d a$ (see below).

Among all caryophyllidean cestodes, $C$. laticeps infects the widest range of fish hosts (38 species of cyprinids), with most hosts from the subfamily Leuciscinae (19 species), especially breams (species of Abramis Cuvier and Ballerus Heckel). Such a wide range of fish hosts (i.e. euryxenous host specificity) is rather unusual among these cestodes, as 
most of them are stenoxenous or oioxenous (Mackiewicz 1972, Scholz and Kuchta 2017, Scholz and Oros 2017). However, some of the records require confirmation, e.g. those reported by Rahemo and Mohammad (2004) from tench, Tinca tinca (Linnaeus) and Carassobarbus luteus (Heckel).

Caryophyllaeus laticeps has a large distribution that includes Europe and most of Palaearctic Asia, even though reports from countries outside of the former USSR are rather scarce (Xi et al. 2016) and need of verification. Significantly, almost nothing is known about the distribution of the individual morphotypes recognised by Hanzelová et al. (2015) outside of Europe. Records of C. laticeps from North America, e.g. that of Rehder (1959) from common carp in Iowa, represent in fact Khawia iowensis Calentine et Ulmer, 1961 (= syn. of K. japonensis [Yamaguti, 1934]) (Mackiewicz 1974, Scholz et al. 2011).

Caryophyllaeus laticeps is by far the most intensively studied species of the genus and one of the most studied fish cestode at all (see Discussion). Ultrastructure of several organ systems and structures such as the tegument, nervous system, vitelline follicles, sperm, and frontal and uterine glands has been studied since the late 1960's (Béguin 1966, Mackiewicz 1968, Bazitov 1979, Richards and Arme 1982a,b, Davydov and Poddubnaya 1988, Davydov et al. 1994, Poddubnaya 1995, 1996, Bruňanská and Kostič 2012, Bruňanská et al. 2013, Biserova et al. 2014). Extensive data on seasonal patterns in the occurrence and maturation of $C$. laticeps in different cyprinids from Europe and the former USSR were reviewed by Chubb (1982); more recent data were provided by Evlanov and Kolokolnikova (1991) and Evlanov et al. (1992).

\section{Caryophyllaeus auriculatus (Kulakovskaya, 1961)}

Figs. 3, 8C

Syn.: Monobothrium auriculatum Kulakovskaya, 1961

Material examined. Six flattened, partly decomposed specimens from Leuciscus danilewskii (Kessler) No. 298-1, Siverskyi Donets, Ukraine, collected on 22 May 1952 (ZIK - not numbered, ZIRAS 1415); two specimens from L. danilewskii No. 433-2, Siverskyi Donets, Ukraine, collected on 16 July 1952, designated as Caryophyllaeus laticeps, but with a strikeout species name.

Diagnosis (based on five specimens from L. danilewskii; see Table 2 for measurements). Body slender to moderately robust, elongated, with maximum width at ovarian region, then steeply narrowing towards posterior extremity. Scolex cuneiform with lateral ('auricular') projections, neck very short or absent. Anteriormost testes close or in short distance from anterior extremity and from anteriormost vitelline follicles. Testes posteriorly reach anterior margin of cirrus-sac. Vas deferens medially not surrounded by vitelline follicles, cirrus-sac oval, internal seminal vesicle not observed. Ovary at distance from posterior margin of body, vagina ventral to uterus. Seminal receptacle anterodorsal to ovarian isthmus, Mehlis' gland posterior to ovarian isthmus. Preovarian vitelline follicles reach to posterior margin of cirrus-sac, anteriormost follicles at short distance from anterior extremity; postovarian vitelline follicles small

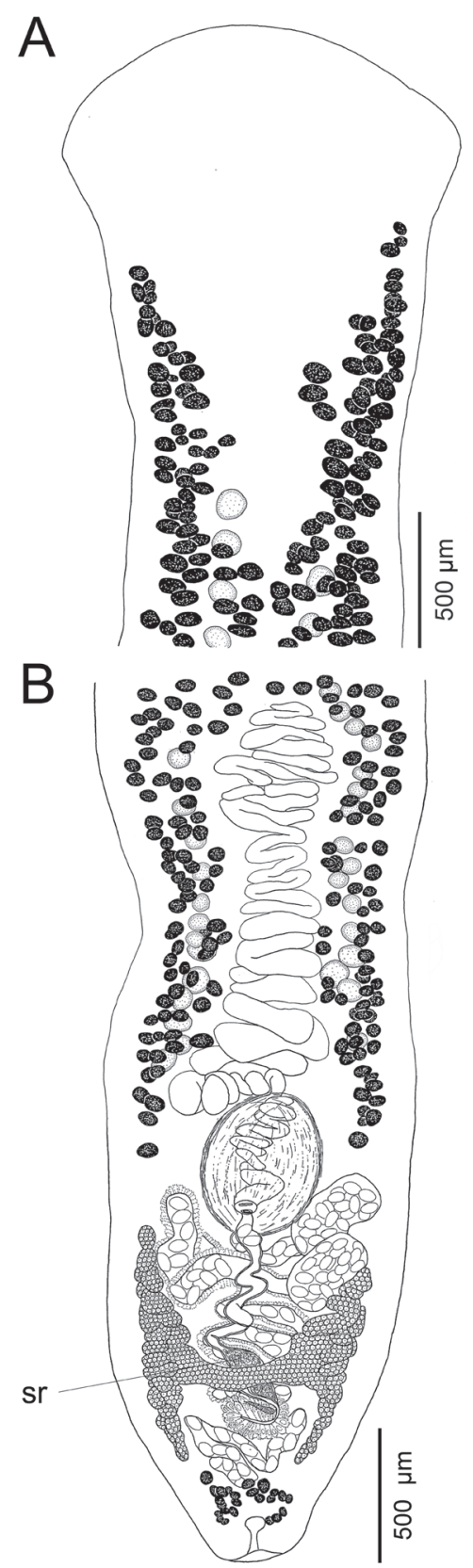

Fig. 3. Caryophyllaeus auriculatus (Kulakovskaya, 1961) from Leuciscus danilewskii (Kessler), Ukraine. A - anterior part of the body (probably syntype; note very short distance of anteriormost vitelline follicles from the narrow scolex); $\mathbf{B}$ - posterior part of the body, ventral view (note low number of postovarian vitelline follicles and presence of seminal receptacle). Abbreviations: $\mathrm{sr}-$ seminal receptacle.

and few (16-28). Uterus forms several loops between cirrus-sac and postovarian vitelline follicles.

Type and only known host: Danilewski's dace, Leuciscus danilewskii (Kessler) (Cyprinidae: Leuciscinae).

Type locality: River Siverskyi Donets (or Seversky Donets in Russian), usually simply called the Donets (sometimes incorrectly called the Northern Donets owing to the confusion of the Russian severnyi with siverskyi), the largest tributary of the River Don, Ukraine.

Type specimens: Not designated, but specimens collected on 22 May 1952 and mounted on slides designated No. 298-1 
apparently belong to a type series.

Sequence data. Not available.

Life cycle. Not known.

Distribution. Europe (Ukraine - see Kulakovskaya 1961, Protasova et al. 1990).

Remarks. Kulakovskaya (1961) described this species as Monobothrium auriculatum from specimens found by N.N. Shevchenko in Danilewski's dace from northeastern Ukraine. The original description was brief and illustrations quite schematic (see fig. 3.1 in Kulakovskaya 1961). Kulakovskaya (1961) placed the species in Monobothrium Diesing, 1863 based on the following morphological characteristics: (i) alleged absence of a seminal receptacle (which is in fact present; see Fig. 3B); (ii) a relatively small cirrus-sac (but resembling that of $C$. laticeps); (iii) shape of the ovary (actually different from the ovary of $M$. wageneri Nybelin, 1922, which is butterfly-shaped, with markedly shorter and wider lateral lobes, whereas C. auriculatus possesses an H-shaped ovary with longer and narrower lateral lobes - see fig. 1A in Scholz 1987); (iv) thick tegument; and (v) large eggs (the two last features are not considered to be suitable for circumscription of genera). Scholz et al. (2015) transferred M. auriculatum, which has never been reported since its original description, to Caryophyllaeus because of its morphology, which markedly differs from that of the type and currently only known species of Monobothrium, M. wageneri.

Caryophyllaeus auriculatus somewhat resembles C. laticeps in its morphology, especially in the shape of the body, scolex and cirrus-sac, and in the appearance of the vas deferens, which forms a long area of tightly coiled loops anterior to the cirrus-sac that is not surrounded by vitelline follicles medially, i.e. on the ventral and dorsal side (see fig. 2 in Hanzelová et al. 2015 and Fig. 1B in the present paper). Both species differ from each other in the number and size of the postovarian vitelline follicles (PVF) (much fewer, i.e. 16-28, and smaller in C. auriculatus vs usually numerous, i.e. more than 30 , but always forming a conspicuous field of PVF due to their larger size in $C$. laticeps), the absence of vitelline follicles alongside the preovarian uterine loops in $C$. auriculatus (present in C. laticeps) and an internal seminal vesicle (usually present in the latter species), and shape of the scolex, which has more prominent anterolateral corners in C. auriculatus.

Caryophyllaeus balticus (Szidat, 1941) comb. n.

Figs. 4, 8D

Syn.: Khawia baltica Szidat, 1941 (new synonym)

Material examined. Forty-seven specimens from Tinca tinca in the Czech Republic (IPCAS C-42) and two specimens from Switzerland (MHNG - not registered) (see Scholz et al. 2011 for details).

Diagnosis (compiled from Scholz et al. 2011; see Table 2 for measurements). Body slender, maximum width at level of cirrus-sac. Scolex flabellate, markedly wider than neck, with wrinkles along front edge; neck long. Anteriormost testes located at very long distance from anterior extremity and far posterior to anteriormost vitelline fol-

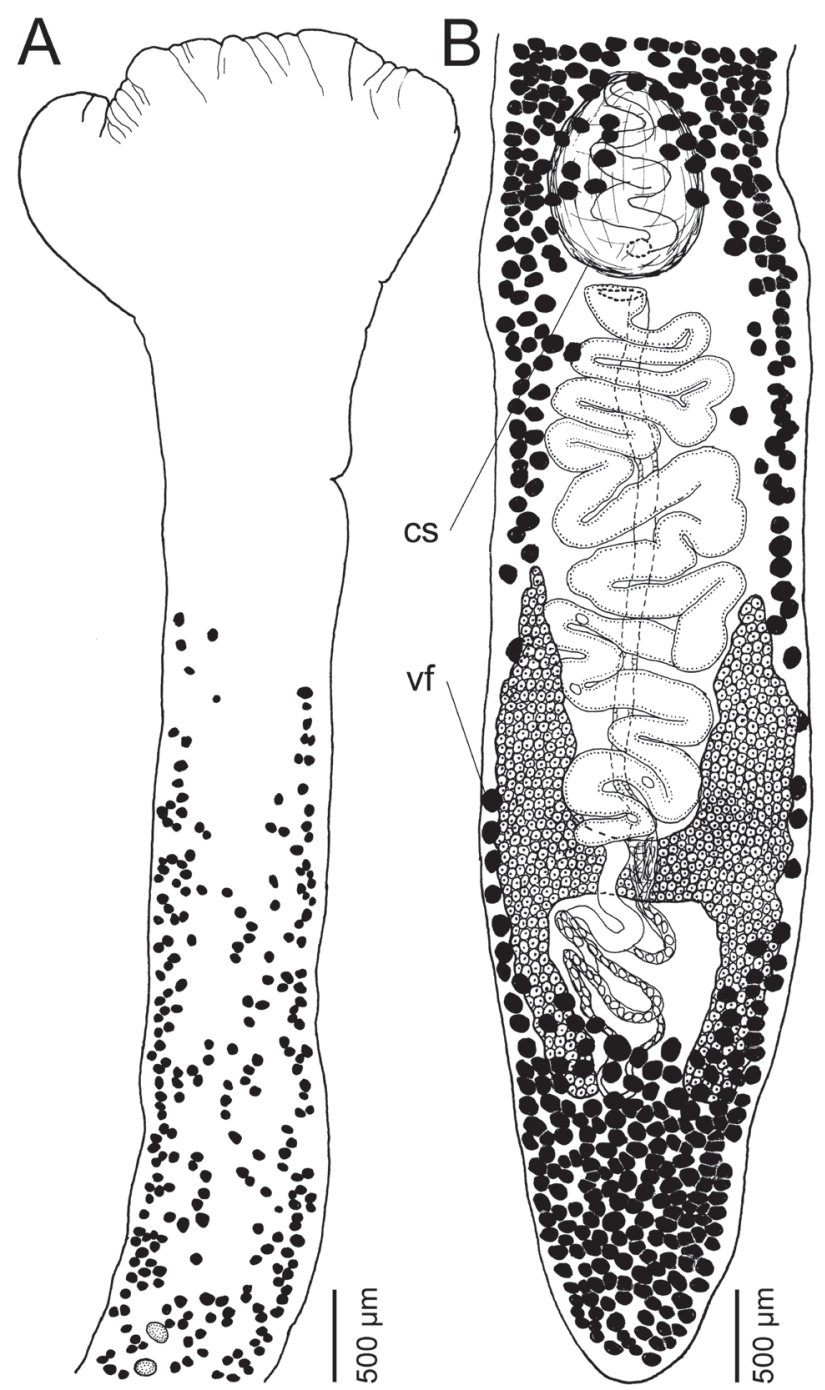

Fig. 4. Caryophyllaeus balticus (Szidat, 1941) comb. n. (syn. Khawia baltica) from Tinca tinca (Linnaeus), Czech Republic. $\mathbf{A}$ - anterior part of the body (note long neck and flabellate scolex); B - posterior part of the body, dorsal view (note small cirrus-sac and vitelline follicles present alongside ovary). $A b$ breviations: cs - cirrus-sac; vf - vitelline follicle. Modified from Scholz et al. (2011a).

licles. Posteriorly, testes reach to anterior margin of cirrus-sac, rarely to its posterior half. Cirrus-sac small, oval, thin-walled, difficult to observe. Ovary bilobed, with long and slender ovarian arms. Vagina slightly sinuous, forming elongated seminal receptacle in its proximal part. Vitelline follicles cortical, usually spherical. Anteriormost vitelline follicles far posterior to anterior extremity, reaching posteriorly alongside cirrus-sac to uterine loops; a few follicles present alongside ovary. Postovarian follicles extensive (several hundreds). Uterine region long, loops of uterus reaching anteriorly to level of posterior margin of cirrus-sac.

Type and only known host: Tench, Tinca tinca Linnaeus (Cyprinidae: Tincinae); records from other fishes are considered to be unreliable (Scholz et al. 2011).

Type locality: Rossitten, Courland Spit (Kuhrische Nehrung), East Prussia (now the Russian enclave of Kaliningrad). 
Type specimens: Do not exist (probably destroyed during the Second World War (Calentine and Ulmer 1961). Neotype (paragenophore IPCAS C-42) from Tinca tinca (host coll. No. 2841a), a fishpond near Jindřichův Hradec $\left(49^{\circ} 8^{\prime} 39^{\prime \prime N}\right.$; $\left.15^{\circ} 0^{\prime} 11 " E\right)$, South Bohemia, Czech Republic, 22. 4. 2010, collected by Roman Kuchta and Céline Levron.

Sequence data. Partial coxl sequence (JN004233), complete nad3 sequence (JN004244), complete ssrDNA sequence (JN004255), partial $l s r$ DNA (JN004266; all Scholz et al. 2011), and complete ITS2 (JQ647870; Králová-Hromadová et al. 2012).

Life cycle. Scholz (1993) demonstrated experimentally that the oligochaete Tubifex tubifex serves as intermediate host; plerocercoids were formed after one month at a temperature of $20-22^{\circ} \mathrm{C}$ (Scholz 1993).

Distribution. Europe (Czech Republic, Lithuania, Poland, Russia - Kaliningrad District, Switzerland, Ukraine), Asia (Georgia) (Scholz et al. 2011, Gibson 2013b).

Remarks. The species was originally described as Khawia baltica by Szidat (1941) and redescribed by Scholz et al. (2011), who assessed interrelations of all seven species of the lytocestid genus Khawia based on ssrDNA, $l s r$ DNA, nad3 and cox 1 sequences. All analyses invariably showed a distant position of $K$. baltica relative to the other species of Khawia (see figs. 9 and 10 in Scholz et al. 2011). Furthermore, a more comprehensive multigene analyses revealed $K$. baltica as a sister taxon to the lineage comprised of C. laticeps and C. brachycollis (see Xi et al. 2013, Scholz et al. 2015), thus making Khawia polyphyletic.

As a member of the family Lytocestidae, $K$. baltica possesses cortical vitelline follicles, whereas all species of Caryophyllaeus are mainly medullary (the new species from Chondrostoma nasus described below has vitelline follicles mainly paramuscular, with some follicles present also in the cortex). There is also another difference between $K$. baltica and species of Caryophyllaeus in the relative length of the uterine region (much longer in the former species). In contrast, $K$. baltica resembles some species of Caryophyllaeus, especially Morphotype 1 of $C$. laticeps, in its possession of a flabellate scolex with numerous, shallow longitudinal grooves (see figs. 1 and 4 in Hanzelová et al. 2015), and a long neck, vitelline follicles present alongside the whole preovarian uterine region, and a less robust ovary with long and slender lateral lobes (Scholz et al. 2011, Hanzelová et al. 2015).

Khawia baltica thus occupies in its morphology an intermediate position between species of Khawia (all with the cortical position of the vitelline follicles) and Caryophyllaeus (all but one species with medullary vitelline follicles), but molecular data unequivocally support a close relationship of this taxon with species of the latter genus (Fig. 9). Moreover, all recent phylogenetic studies have demonstrated that the position of the vitelline follicles and testes in relation to the inner longitudinal musculature is a homoplastic character that does not reflect the interrelationships of the caryophyllidean cestodes and their evolutionary history (Oros et al. 2008, Brabec et al. 2012, Scholz et al. 2015). Consequently, K. baltica is transferred to Caryophyllaeus as a new combination and the generic diag-

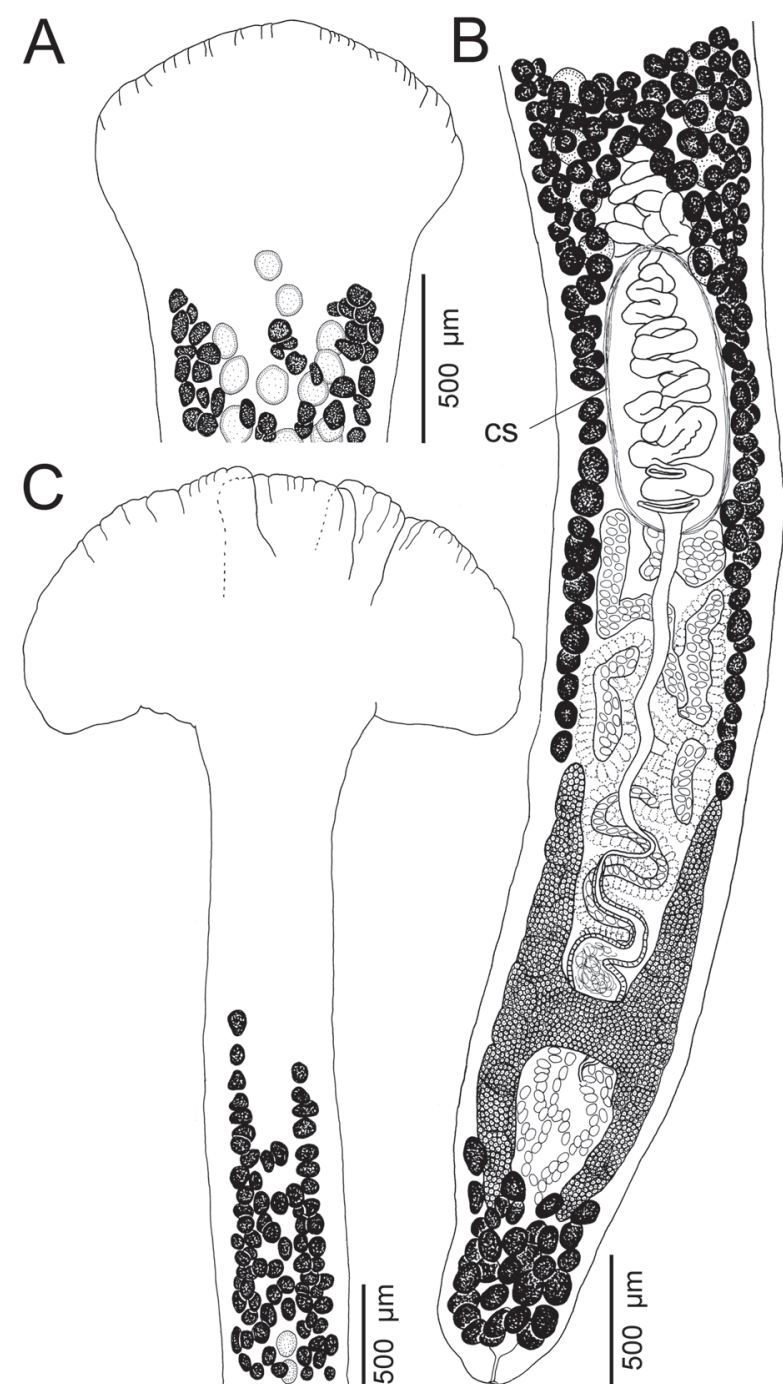

Fig. 5. Caryophyllaeus brachycollis Janiszewska, 1953 from Barbus carpathicus Kotlík, Tsigenopoulos, Ráb et Berrebi, Slovakia (A) and from Abramis brama (Linnaeus), Slovakia (B, C). A, C - anterior parts of body of morphotypes described by Barčák et al. (2014). B - posterior part of body, ventral view (note muscular, elongated cirrus-sac). Abbreviation: cs - cirrus-sac.

nosis of Caryophyllaeus is emended to reflect the cortical position of the vitelline follicles in this species.

\section{Caryophyllaeus brachycollis Janiszewska, 1953}

Figs. 5, 8G,H

Syn.: Caryophyllaeus laticeps (Pallas, 1781) pro parte

Material examined. See Barčák et al. (2014) and Bazsalovicsová et al. (2014); additionally, one specimen of Morphotype 1 from Alburnus neretvae Buj, Sanda et Perea (host No. ALNE 2), Mušnica stream near Avtovac, Bosnia and Herzegovina, 6 July 2015 (IPCAS C-51/11); one specimen of Morphotype 1 from Squalius squalus (Bonaparte) (host No. SQSQ 16), Drežnica, Croatia, 10 October 2016 (IPCAS C-51/10); one specimen of Morphotype 2 from Pseudochondrostoma polylepis (Steindachner) (host No. PSPO 25), Alcoa, Fervença, Portugal, 25 June 2016 (IPCAS C-51/12), collected by Andrea Vetešníková Šimková (all fishes represent new host records). 
Diagnosis (compiled from Barčák et al. 2014 who described two morphotypes called herein M1 (Figs. 5A, 8G) and M2 (Figs. 5C, 8H; see Table 2 for measurements). Body robust (M1) or slender (M2), elongated, with maximum width at level of cirrus-sac, then narrowing towards posterior extremity. Scolex spatulate, with tapered anterior edge (M1) or flabellate with curved anterior margin (M2), slightly (M1) or markedly (M2) wider that neck. Testes oval to subspherical, intermingled with vitelline follicles; anteriormost testes close (M1) or at long distance from scolex (M2); posteriorly testes reach anterior margin of cirrus-sac. Vas deferens surrounded by vitelline follicles. Cirrus-sac large, thick-walled, elongated to ovoid, containing long, muscular cirrus. Internal seminal vesicle absent. Ovary follicular. Vagina sinuous in its proximal part, almost straight distally. Seminal receptacle oval to subspherical, anterodorsal to ovarian isthmus. Preovarian vitelline follicles lateral and median, surrounding testes and distal (posterior) part of vas deferens; postovarian vitelline follicles numerous (several dozens). Uterine region moderately long.

Type host: Not indicated by Janiszewska (1953), who found cestodes in four species of cyprinids (Cyprinidae) from two subfamilies, Barbus barbus (Linnaeus), B. petenyi Heckel (both Barbinae), Squalius cephalus and Leuciscus idus (Linnaeus) (both Leuciscinae).

Additional hosts: Cyprinid fishes of the subfamilies Alburninae (2 species), Barbinae (8), Cyprininae (1) and Leuciscinae (15).

Type locality: Not specified explicitly, but tapeworms were found in rivers in Poland (the Rivers Odra and Vistula and their tributaries Barycz, Raba and Ropa).

Type specimens: Barč́k et al. (2014) designated the specimen found in Barbus barbus from the Argens River near Marseille, France (IPCAS C-3/5) as the neotype of C. brachycollis because type specimens were not preserved by Janiszewska (1953).

Sequence data. Partial coxl sequences (JQ034064; Brabec et al. 2012; KF051100, KF051105, KF051106, KF051109-KF051113, KF051121-KF051124, KF051133 -KF051136; Bazsalovicsová et al. 2014), complete nad3 sequences (JQ034001; Brabec et al. 2012), partial $l s r$ DNA sequences (JQ034120; Brabec et al. 2012; KF051137KF051140, KF051154-KF051158, KF051166-KF051168, KF051170, KF051174, KF051175, KF051181; Bazsalovicsová et al. 2014), partial ssrDNA sequences (JQ034137; Brabec et al. 2012), and complete ITS2 sequences (KF700248, KF700249; Králová-Hromadová et al. 2013). New partial $l s r$ DNA sequences of specimens from Alburnus neretvae in Bosnia and Herzegovina (KY617021), Squalius squalus in Croatia (KY617019) and Pseudochondrostoma polylepis in Portugal (KY617020).

Life cycle. Janiszewska $(1953,1954)$ reported a metacestode (plerocercoid according to the terminology proposed by Chervy 2002) allegedly belonging to C. brachycollis, from Limnodrilus udekemianus Claparède and L. hoffmeisteri Claparède (Naididae: Tubificinae) both in Poland. Kulakovskaya (1962) successfully infected L. hoffmeisteri and Tubifex tubifex with oncospheres of
C. brachycollis and found plerocercoids infective for fish after 3-4 months of development in the intermediate hosts; metacestodes may survive up to 2 years (Protasova et al. 1990).

Distribution (new geographical records marked with an asterisk). Europe (Austria, *Bosnia and Herzegovina, Bulgaria, *Croatia, Czech Republic, Finland, France, Greece, Hungary, Italy, Montenegro, Poland, Portugal, Russia, Serbia, Slovakia and Ukraine) and Palaearctic Asia (China, Iraq and Russia) (see Gibson 2013c and Barčák et al. 2014 for references and verified records).

Remarks. Barčák et al. (2014) redescribed this species and characterised two morphotypes that differ conspicuously from one another mainly in the shape of the scolex and the anterior extent of the vitelline follicles and testes. This cestode occurs in a wide spectrum of cyprinid fishes, but it is most frequent and abundant in barbels (Barbinae) and chub, Squalius cephalus (Morphotype 1) and breams (A. brama, Ballerus spp.; Morphotype 2). All records from Asia should be verified, especially those from Iraq and China.

\section{Caryophyllaeus fimbriceps Annenkova-Chlopina, 1919} Figs. 6A,B; 8F

Material examined. Fourteen and 27 strongly flattened and deformed specimens from Cyprinus carpio in the Czech Republic and Slovakia, respectively; two specimens from 'sazan' (wild form of C. carpio) in Zelenga Lake (ZIRAS No. 1360) and in the River Volga (ZIRAS No. 1371), Russia; eight specimens from Tinca tinca, Czech Republic (Scholz 1989).

Diagnosis (based on five specimens from C. carpio, Czech Republic; see Table 2 for measurements). Body elongated, moderately robust, with maximum width at level of cirrus-sac, then narrowing towards posterior end. Scolex cuneicrispitate, i.e. flabellate with short conspicuous indentations on anterior margin, neck short. Anteriormost testes far from anterior extremity and in moderate distance from anteriormost vitelline follicles, testes posteriorly reach anterior margin of cirrus-sac. Area filled with vas deferens very short, difficult to observe. Cirrus-sac spherical to oval; internal seminal vesicle absent. Preovarian vitelline follicles medullary, anteriormost vitelline follicles not far from anterior extremity, posteriorly reach up to anterior margin of ovarian arms, i.e. absent alongside ovary; postovarian vitelline follicles numerous (several dozens). Ovary close to posterior margin of body; vagina slightly sinuous; seminal receptacle dorsal to ovarian isthmus. Uterus forms several loops between cirrus-sac and postovarian vitelline follicles.

Type host: Common carp, Cyprinus carpio Linnaeus (Cyprinidae: Cyprininae).

Additional hosts: In addition to common carp, the following cyprinid fishes have been reported by Dubinina (1987) and Protasova et al. (1990) (but all these fish hosts should be verified): Abramis brama, Alburnus alburnus (Linnaeus), Ballerus sapa, Carassius carassius, Chondrostoma polylepis (syn. Pseudochondrostoma polylepis [Steindachner]), Leuciscus idus, L. leuciscus (Linnaeus), Rutilus rutilus (Linnaeus), 

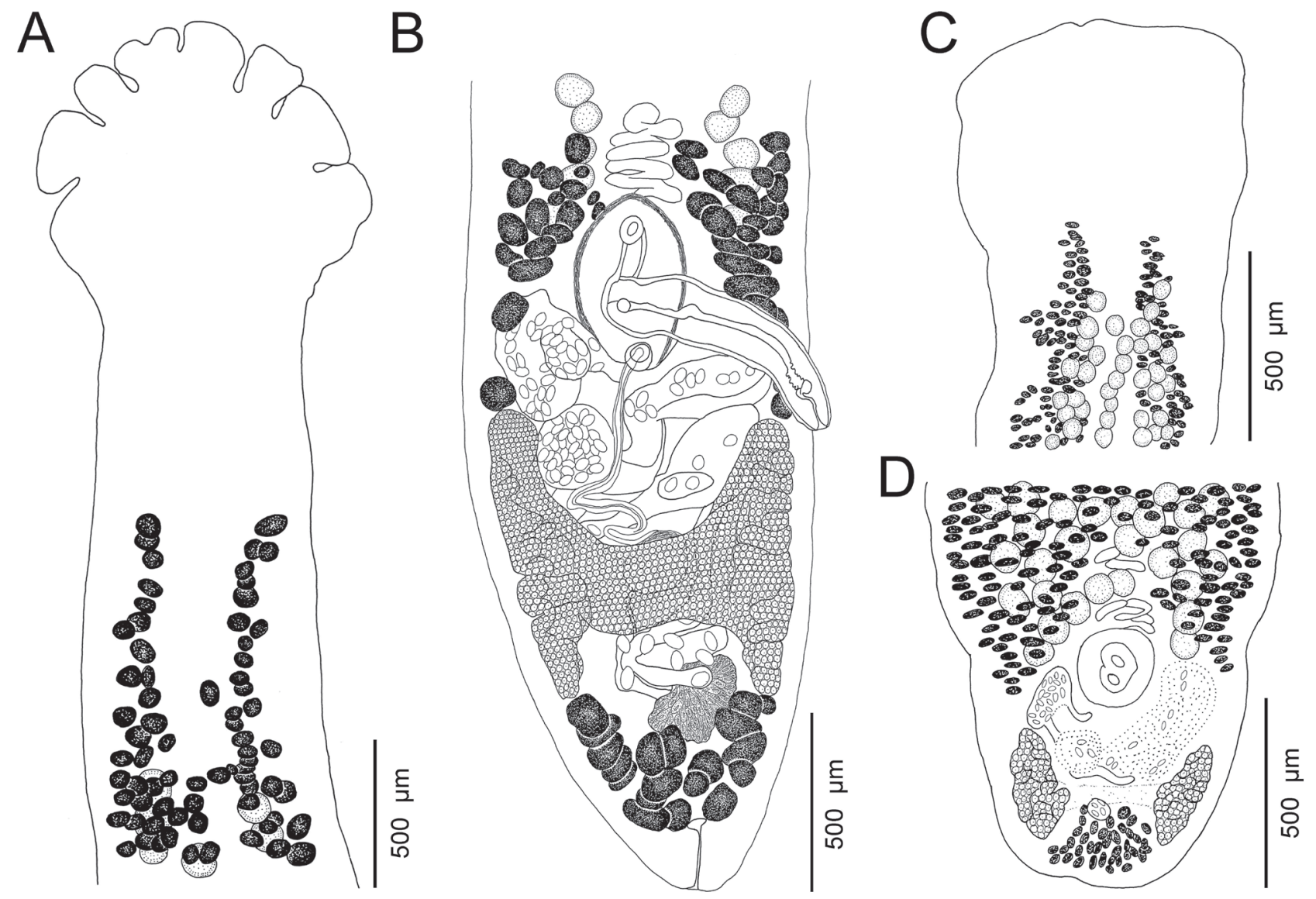

Fig. 6. Caryophyllaeus fimbriceps Annenkova-Chlopina, 1919 from wild population of common carp ('sazan'), Cyprinus carpio Linnaeus, Russia (A, B). Caryophyllaeus syrdarjensis from Schizothorax intermedius McClelland (= S. curvifrons Heckel). Redrawn from Skrjabin (1913) (C, D). A, C - anterior part of body. B - posterior part of body, ventral view. D - posterior part of body, probably ventral view (Skrjabin 1913 did not provide this information).

Squalius cephalus, Vimba vimba (Linnaeus) and Tinca tinca. Especially doubtful are records from Coregonus wartmanni (Bloch) (Salmonidae) and Huso huso (Linnaeus) (Acipenceridae).

Type locality: Not explicitly specified (specimens described were found in carp from Caucasus and the Caspian Sea - see table in Annenkova-Chlopina 1919).

Type specimens: Not known to exist, almost certainly never deposited.

Sequence data. Not available.

Life cycle. Several naidids (Tubificinae), namely Psammoryctes albicola (Michaelsen), Psammoryctides barbatus, Limnodrilus claparedeanus, L. udekemianus, Tubifex ignotus (Štolc) and T. tubifex, serve as intermediate hosts (Demshin 1984, Protasova et al. 1990).

Distribution. Europe (Austria, Belorussia, Bulgaria, Czech Republic, Great Britain, Greece, Hungary, Italy, Latvia, Lithuania, Poland, Romania, Russia - Karelia and the River Volga basin, Serbia, Slovakia, Spain and Ukraine), Asia (rivers and fish cultures in the basins of the Azov, Black and Caspian Seas and Lake Aral, Azerbaijan, Georgia, Iran, Kazakhstan, Kyrgyztan, Tadjikistan; introduced with carp to western Siberia) (Dubinina 1962, 1987, Gibson et al. 2005, Gibson 2013d).

Remarks. This cestode was described by Annenkova-Chlopina (1919) from 'sazan', which is the name used for wild common carp. Dogiel and Bykhovsky (1939) distinguished $C$. fimbriceps from $C$. laticeps by the shape of the scolex, which possesses deep notches on the anterior edge in the former species, and a smaller size of the body, with gravid, i.e. egg-bearing, specimens only $3.5 \mathrm{~mm}$ long (mostly longer than $6 \mathrm{~mm}$ in C. laticeps). Common carp is apparently the principal definitive host, whereas records from other fish need verification.

In the 1950's and 1960's, C. fimbriceps was listed among pathogenic parasites of cultured carp as it caused slower growth or even mortality of heavily infected fry and yearlings (Kulakovskaya and Svirepo 1967, Bauer et al. 1973). Mitterpák and Huňady (1984) reported an epizootic outbreak of infection with $C$. fimbriceps, which resulted in considerable losses among young carps (1 and 2-years old) in eastern Slovakia. However, only very few, unverified records of $C$. fimbriceps have been published since then, e.g. from Serbia (Dikanović et al. 2013) and Iran (Sattari et al. 2007). Reports of cestodes allegedly belonging to C. fimbriceps from freshwater bream, Abramis brama, in Poland, Romania and Russia in the 1980's (Georgescu and Naziru 1984, Vasilevskaya 1984, Reda 1988) and Caspian roach, Rutilus caspicus (Yakovlev), in Iran (Khara et al. 2011) need verification, because the authors did not provide morphological descriptions nor line-drawings and no vouchers are available. 
Long-term effort of the present authors to find C. fimbriceps failed, which well corresponds to a considerable decrease of reliable reports of this cestode since the 1970's. The absence of recent records indicates possible extinction of this cestode in Europe. Disappearance of this previously common parasite of carp may be related to introduction of invasive cestodes parasitising the same fish host, such as the caryophyllideans Khawia sinensis Hsü, 1935 and Atractolytocestus huronensis Anthony, 1958, and the bothriocephalidean Schyzocotyle acheilognathi (Yamaguti, 1934) (syn. Bothriocephalus acheilognathi Yamaguti, 1934) (Musselius et al. 1964, Körting 1975, Kennedy 1994, Oros et al. 2004, 2009, Scholz et al. 2012). Molecular data on $C$. fimbriceps are thus not available and morphological and molecular study of the species based on new material is pending.

\section{Caryophyllaeus syrdarjensis Skrjabin, 1913 Fig. 6C,D}

Material examined. None.

Diagnosis (based on Skrjabin 1913; see Table 2 for measurements). Body robust, more flattened anteriorly, becoming widely oval in cross section posteriorly, with maximum width at level of cirrus-sac, then narrowing towards widely rounded posterior end. Scolex cuneiform, without any obvious grooves on anterior edge, only slightly wider than neck region. Testes almost spherical, intermingled with vitelline follicles. Anteriormost testes close to anterior extremity and always posterior to anteriormost vitelline follicles. Posteriorly, follicles reach to mid-length of cirrus-sac. Vas deferens strongly coiled, occupies large region anterior to cirrus-sac, surrounded by vitelline follicles and testes in posterior (distal) part. Cirrus-sac relatively small, strongly muscular, subspherical (elongated in sagittal section), close to posterior end of body. Internal seminal vesicle small. Ovary with short and narrow lateral lobes, very close to posterior extremity. Vagina described to be identical as in C. laticeps, apparently joining uterus to form short common uterovaginal duct. Seminal receptacle not reported. Preovarian vitelline follicles transversely elongated, much smaller than testes; anteriormost vitelline follicles begin at short distance posterior to anterior extremity; posteriorly, follicles reach level of posterior part of cirrus-sac, rarely reaching to ovarian lobes. Postovarian follicles form relatively small group. Uterus forms several strongly coiled loops between ovary and posterior part of cirrus-sac. Genital pores open in genital atrium, i.e. not opening separately outside.

Type and only known host: Sattar snowtrout, Schizothorax intermedius McClelland (= Schizothorax curvifrons Heckel) (Cyprinidae: Barbinae); record of C. syrdarjensis from Barbus barbus (Cyprinidae: Barbinae) in Ukraine in an unpublished summary of DSc. thesis by Kulakovskaya (1969) is apparently erroneous.

Ty pe lo c a lity: River Talas, Syr Darya basin, "Russisch-Turkestan" (in fact part of Kyrgyzstan or Kazakhstan).

Type specimens: Not known to exist, almost certainly never preserved; Skrjabin (1913) did not indicate their deposition and they were not found in the two principal helmintholog- ical collections of the former Soviet Union, i.e. ZIRAS in St. Petersburg and collection of the former Helminthological Laboratory of the Russian Academy of Sciences (GELAN) in Moscow (T.S. - unpubl. data).

Sequence data. Not available.

Life cycle. Not known.

Distribution. The River Talas basin in former Russian-Turkestan district (contemporary area of Kazakhstan and Kyrgyzstan); since record of C. syrdarjensis from Ukraine (see above) is considered erroneous, the species has never been found since its original description.

Remarks. Skrjabin (1913) described this species from 15 specimens found in Schizothorax intermedius (=S. curvifrons) from the River Talas basin; prevalence of infection was 10\% (2 fish infected of 20 examined). Morphological description of $C$. syrdarjensis was relatively detailed, but only few measurements were provided. In a simple identification key, the new species was differentiated from $C$. laticeps by a more developed vas deferens, which occupies a large area anterior to the cirrus-sac ("Vas deferens bildet von der Bursa cirri ein mächtiges Schlingengewirr"). It seems that all specimens studied by Skrjabin (1913) were strongly contracted; the posterior region of the specimens illustrated on figs. 4 and 8 is very short, especially the uterine region, thus indicating that the worms may have been unnaturally deformed during fixation.

Nybelin (1922) recognised C. syrdarjensis as a valid species. Dubinina (1962) and Protasova et al. (1990) did not include this species in their lists of fish cestodes from ex-Soviet Union, but Dubinina (1987) listed C. syrdarjensis among the species of Caryophyllaeus occurring in the former USSR. In a footnote, she mentioned incorrect synonymy of this species with $C$. fimbriceps by Dogiel and Bykhovsky (1939) and possible conspecificity of C. syrdarjensis and $C$. brachycollis. It is true that the scolex of C. syrdarjensis (see fig. 3 in Skrjabin 1913) somewhat resembles that of Morphotype 1 of $C$. brachycollis (see figs. 1 and 4A in Barčák et al. 2014); both species also have the anteriormost vitelline follicles and testes situated close to the anterior extremity. However, the posterior end of both species is conspicuously different, including the shape and position of the ovary and cirrus-sac, the latter being much larger in C. brachycollis (see figs. 2 and 3 in Barčák et al. 2014 and figs 4, 7 and 8 in Skrjabin 1913). In addition, $C$. syrdarjensis occurs in snowtrouts (species of Schizothorax Heckel) that live only in Central and East Asia, whereas $C$. brachycollis is largely a European species.

Caryophyllaeus chondrostomi $\mathrm{sp} . \mathrm{n}$.

Figs. 7, 8E

ZooBank number for species:

urn:1sid:zoobank.org:act:77D40E4C-CDEC-4B39-87F8-4ACB716C5ECF

Syn.: Caryophyllaeus laticeps morphotype 4 of Bazsalovicsová et al. (2014) and Hanzelová et al. (2015).

Material examined. Fifty seven specimens from Chondrostoma nasus, River Drau, Austria, collected by F. Jirsa in 2000 and by T.S. and A. Ash in 2009 (IPCAS No. 


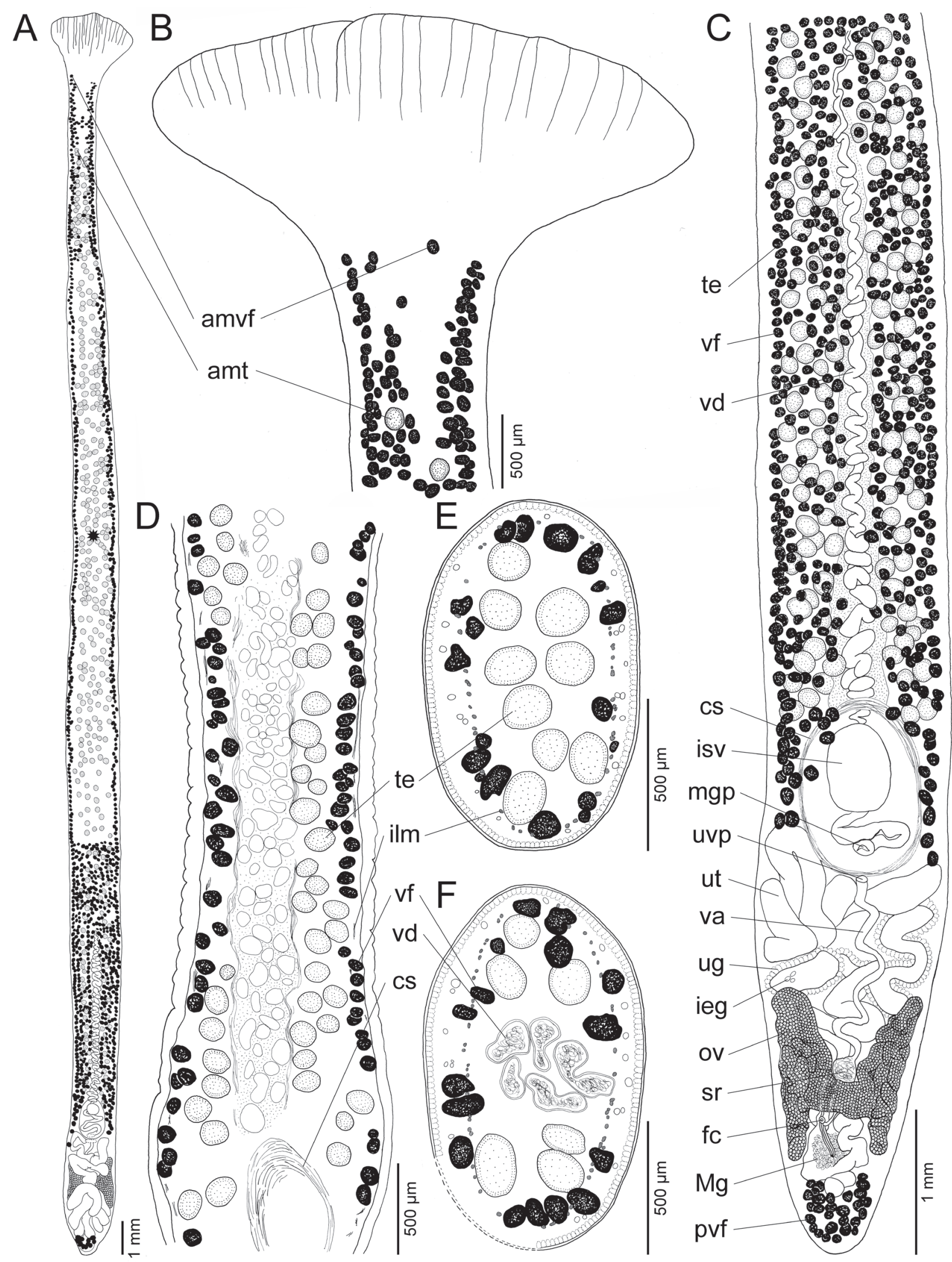

Fig. 7. Caryophyllaeus chondrostomi sp. n. from Chondrostoma nasus (Linnaeus), Austria. A - outline of whole body, dorsal view (* vitelline follicles in middle part not illustrated); $\mathbf{B}$ - anterior part of body (note width of scolex and relatively short distance of first testes from anterior margin of body); $\mathbf{C}$ - posterior part of body with conspicuous vas deferens, ventral view; $\mathbf{D}$ - longitudinal section of posterior part of body; $\mathbf{E}$ - cross section of middle part of body; $\mathbf{F}$ - cross section on level of vas deferens (D-F: note medullary, paramuscular and even cortical position of vitelline follicles). Abbreviations: amt - anteriormost testis; amvf - anteriormost vitelline follicle; cs - cirrus-sac; fc - fertilisation canal; ieg - intrauterine eggs; ilm - inner longitudinal musculature; isv - internal seminal vesicle; $\mathrm{Mg}$ - Mehlis' gland; mgp - male genital pore; ov - ovary; pvf - postovarian vitelline follicles; sr - seminal receptacle; te - testes; ug - uterine glands; ut - uterus; uvp - uterovaginal pore; va - vagina; vd - vas deferens; vf - vitelline follicles. 

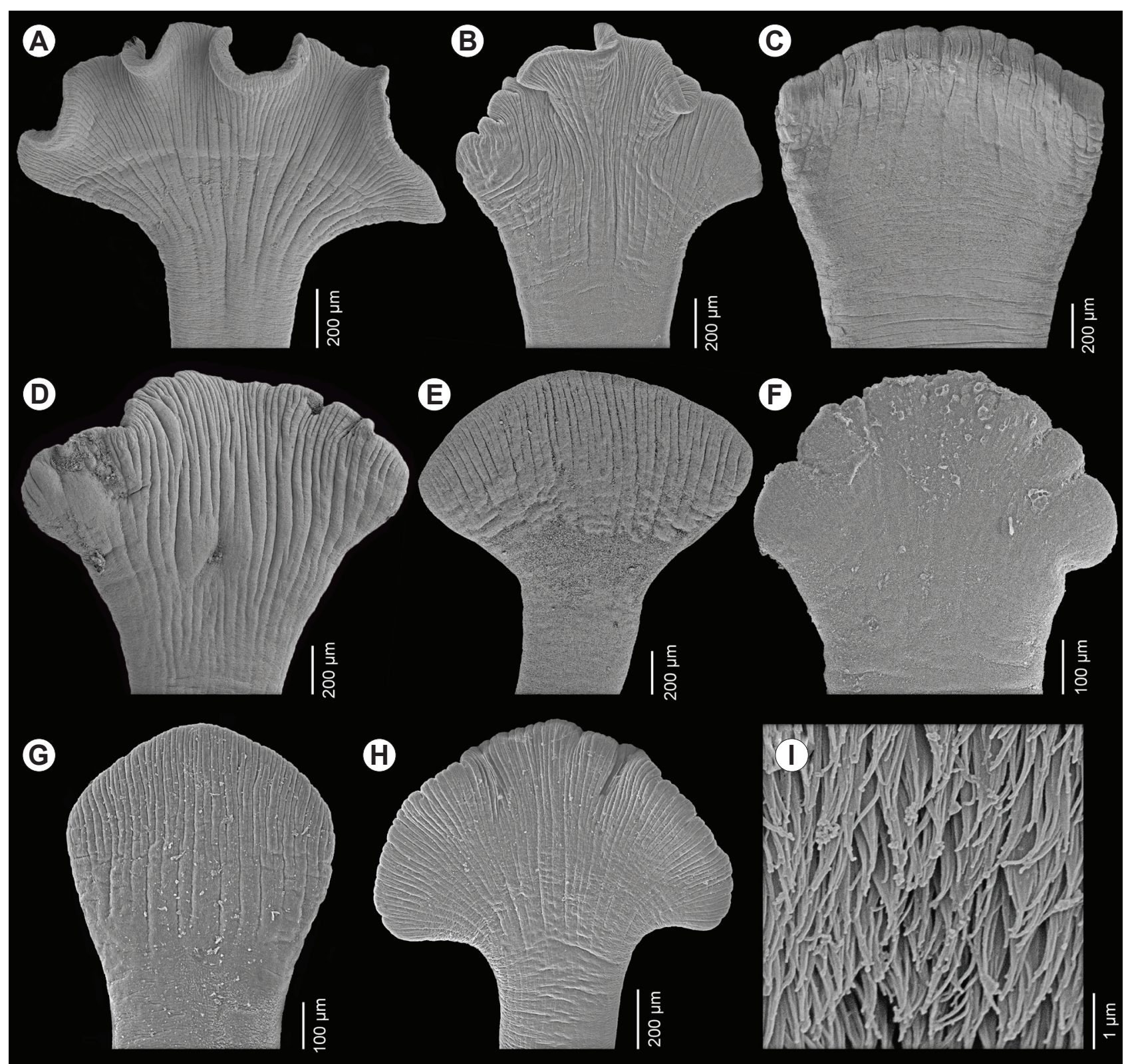

Fig. 8. Scanning electron microphotographs of the scoleces of species of Caryophyllaeus Gmelin, 1790 (A-H). A - flabellate scolex with folds of $C$. laticeps (Pallas, 1781) from Abramis brama (Linnaeus) (Slovakia); B - cuneicrispitate scolex of C. laticeps from Cyprinus carpio Linnaeus (Italy); C - cuneiform scolex with lateral ('auricular') projections of C. auriculatus (Kulakovskaya, 1961) from Leuciscus danilewskii (Kessler) (Ukraine); D - flabellate scolex with wrinkles along front edge of C. balticus (Szidat, 1941) from Tinca tinca (Linnaeus) (Czech Republic); $\mathbf{E}$ - flabellate scolex of C. chondrostomi sp. n. from Chondrosoma nasus (Linnaeus) (Austria); $\mathbf{F}$ - cuneicrispitate scolex of immature C. fimbriceps Annenkova-Chlopina, 1919 from Cyprinus carpio (Slovakia); G - spatulate scolex with tapered edge of Morphotype 1 of C. brachycollis Janiszewska, 1953 from Barbus carpathicus (Kotlík, Tsigenopoulos, Ráb et Berrebi) (Slovakia); $\mathbf{H}$ - flabellate scolex with curved margin of Morphotype 2 of C. brachycollis from A. brama (Slovakia); I - acicular filitriches (filiform microtriches) on scolex of $C$. laticeps from Cyprinus carpio (Italy).

C-748), and River Hron, Slovakia in 1958 by R. Žitňan (IPSAS Nos. 706/58, 707/58, 718/58, 720/58, 849/58, 863/58).

Diagnosis (based on 15 specimens from C. nasus, Austria; see Table 2 for measurements). Body large, robust, with maximum width at level of cirrus-sac, then narrowing towards posterior end. Surface uniformly covered by acicular filitriches (filiform microtriches). Scolex afossate, flabellate, with small wrinkles on anterior margin, much wider than relatively slender neck; its anterior margin with numerous superficial grooves (wrinkles). Inner longitudinal musculature well developed, formed by small bundles of muscle fibres. Testes medullary, numerous, anteriormost testes always posterior to anteriormost vitelline follicles, in short distance from anterior margin of body and anteriormost vitelline follicles, posteriorly reaching posterior margin of cirrus-sac. Vas deferens very long, strongly coiled, distal (posterior) part not surrounded by vitelline follicles nor testes medially. Cirrus-sac large, pyriform to oval, thin-walled; internal seminal vesicle spherical, large. Pre- 
ovarian vitelline follicles small, some of them penetrate to cortex, i.e. paramuscular or even cortical in position. Anteriormost vitelline follicles in relatively short distance from anterior margin of scolex, posteriorly reach ovarian arms. Postovarian vitelline follicles numerous (several dozens). Ovary H-shaped, follicular, close to posterior margin of body. Vagina slightly sinuous tube, ventral to uterus, joins with uterus and forms short common uterovaginal duct; seminal receptacle dorsal to ovarian isthmus. Uterus forms several loops between postovarian vitelline follicles and cirrus-sac; preovarian part surrounded by numerous glands. Genital pores separated, close to one another, male pore always anterior to female (common uterovaginal) pore. Eggs smooth, operculate and unembryonated (without formed oncosphere in utero).

Type and only known host: Common nase Chondrostoma nasus (Linnaeus) (Cyprinidae: Leuciscinae).

Type locality: River Drau near Rosegg, Carinthia, Austria $\left(46^{\circ} 35^{\prime} \mathrm{N} ; 14^{\circ} 01^{\prime} \mathrm{E}\right)$.

Type specimens: Holotype - one specimen from host No. AU 2 captured and examined on 28 July 2009, ten paratypes on six slides including three hologenophores (see Pleijel et al. 2008 for terminology) from hosts Nos. AU 2 (one specimen) and AU 3 (nine specimens) captured and examined on 28 July 2009 - all IPCAS C-748; four paratypes from hosts Nos. AU 2 (two specimens) and AU 3 (two specimens) - BMNH 2017.3.20.12-13; four paratypes from hosts Nos. AU 2 (two specimens) and AU 3 (two specimens) - MHNG-PLAT 97005, 97006; four paratypes from hosts Nos. AU 2 (two specimens) and AU 3 (two specimens) - USNM 1422206 and USNM 1422205 , respectively.

Etymology: The new species is named after generic name of its type host, i.e. Chondrostoma.

Sequence data. Partial coxl sequences (KF051128KF051130; Bazsalovicsová et al. 2014) and partial $l s r$ DNA sequences (KF051178-KF051180; Bazsalovicsová et al. 2014).

Life cycle. Not known.

Distribution. Europe (Austria, Slovakia).

Remarks. Tapeworms from C. nasus had been originally considered by the present authors to represent a new, undescribed species related to C. laticeps, because of several morphological peculiarities: (i) a large, very robust body ( $v s$ slender or moderately robust body in other congeners), (ii) scolex significantly wider than neck ( $v s$ scolex only slightly wider in C. auriculatus and C. syrdarjensis), (iii) anteriormost testes in a relatively short distance from the anterior extremity ( $v s$ relatively far distance of anteriormost testes from the anterior extremity in $C$. laticeps, C. balticus and C. fimbriceps), (iv) anteriormost vitelline follicles located in shorter distance to the anterior extremity ( $v s$ longer distance from the anteriormost vitelline follicles from the anterior margin of the body in Morphotypes 1, 3 and 5 of $C$. laticeps - see Hanzelová et al. 2015, C. balticus and Morphotype 2 of C. brachycollis - see Barčák et al. 2014), and (v) long vas deferens not surrounded by vitelline follicles alongside the median line ( $v s$ vas deferens surrounded by vitelline follicles in its distal, i.e. posterior part and thus hardly observable in C. balticus, C. brachycollis and C. fimbriceps).

However, Bazsalovicsová et al. (2014) did not find sufficient genetic support for separate status of tapeworms from common nase (see fig. 1 in Bazsalovicsová et al. 2014). As a result, these large-sized tapeworms were designated as Morphotype 4 of $C$. laticeps and Hanzelová et al. (2015) provided their detailed morphological and biometrical characterisation. In contrast, a recent population genetic analysis of isolates originally identified as $C$. laticeps from Austria, Bulgaria, Slovakia, Russia and United Kingdom using microsatellite loci revealed a considerable genetic difference of the population from C. nasus in Austria from the remaining isolates found in other fish hosts. The microsatellite data analysed with Structure 2.3.4 and Principal Coordinates Analysis (PCoA) programs demonstrated a significant genetic separation of the Austrian population with no overlaps with other populations of $C$. laticeps (I. Hromadová, Institute of Parasitology of the Slovak Academy of Sciences, Košice - unpubl. data).

Together with the existence of unique morphological traits observed in the cestodes from $C$. nasus, these results of the microsatellite analysis led us to reconsider our previous conclusion. Therefore, tapeworms from common nase in Austria are described herein as a new species. Specimens from the same fish host found by R. Žitňan were strongly flattened, which affected considerably their morphology. However, they possess typical characteristics of $C$. chondrostomi sp. n., i.e. large-sized body, with a very long region filled with loops of sperm ducts (vas deferens), large internal seminal vesicle, vitelline follicles beginning anteriorly near the scolex, and thus are considered conspecific.

\section{Invalid species or taxa of uncertain taxonomic status}

\section{Caryophyllaeus kashmirenses Mehra, 1930 - species inquirenda}

This species, the name of which was misspelled as kashmirenses instead of kashmirensis, was insufficiently described in an abstract from the 17th Indian Science Congress held in Allahabad, India, by Mehra (1930). The original description of tapeworms found in Schizothorax micropogon Heckel (currently a synonym of S. curvifrons) from Srinagar, Kashmir, India, contains only basic data on the worms' morphology (Mehra 1930): Worms large, 30-60 mm long; maximum width 1-2 mm. Scolex always wider that body, devoid of any longitudinal grooves. In ovarian region, 10-13 main excretory canals present. Vas deferens strongly coiled. Vaginal canal tubular, nearly straight. Preovarian vitelline follicles cortical, postovarian follicles medullary; a few vitelline follicles may be present alongside ovary. Uterus forms numerous loops never extending anterior to female gonopore. Genital pores situated at last $10-20 \%$ of body length. Eggs $45-53 \mu \mathrm{m} \times$ 30-33 $\mu \mathrm{m}$.

The original description did not contain any illustration nor explicit differential diagnosis of the new species. Mehra (1930) only stated that "The species apparently connects 
the two genera, Caryophyllaeus and Lytocestus." Indeed, the cortical position of the preovarian vitelline follicles (but without any evidence in the form of cross sections) is typical of cestodes of the family Lytocestidae, not those of the Caryophyllaeidae (see Mackiewicz 1994).

Caryophyllaeus kashmirenses was found in the same fish host as $C$. syrdarjensis and in a relatively close region. Another caryophyllidean, the capingentid Adenoscolex oreini Fotedar, 1958, was found in the congeneric host, Oreinus sinuatus (Heckel), in fact misapplied name for Schizothorax richardsonii (Gray), from the same region (Kashmir, India) as C. kashmirenses (see Fotedar 1958).

However, these three species, for which molecular data are not available, are not synonymised herein because of the differences in their position of vitelline follicles (allegedly cortical in C. kashmirenses, but paramuscular in A. oreini - see fig. 7 in Fotedar 1958, and medullary in C. syrdarjensis - fig. 6 in Skrjabin 1913), body size (the two former taxa are large, robust worms up to $60 \mathrm{~mm}$ and $38 \mathrm{~mm}$ long, respectively, whereas C. syrdarjensis is only $16 \mathrm{~mm}$ long), and presumably different shape of the scolex (that of C. kashmirenses was reported as always wider than the body, whereas those of $C$. syrdarjensis and $A$. oreini are only slightly wider than the neck region (see fig. 3 in Skrjabin 1913 and fig. 1 in Fotedar 1958).

Nevertheless, the taxonomic status of C. kashmirenses is uncertain and new material is needed to confirm validity of this species. From A. oreini, C. kashmirenses also differs by having much smaller eggs $(45-53 \mu \mathrm{m} \times 30-33 \mu \mathrm{m} v \mathrm{~s}$ 64-75 $\mu \mathrm{m} \times 36-48 \mu \mathrm{m}$ in $A$. oreini), fewer excretory canals (10-13 vs 14-18) and vitelline follicles present alongside the ovary (absent in A. oreini - see fig. 2 in Fotedar 1958). However, these differential characteristics cannot be confirmed by a study of type specimens, because only types of A. oreini are available at BMNH (1998.10.13.8-10).

Caryophyllaeus prussicus (Szidat, 1937) comb. n. species inquirenda

Syns.: Bothrioscolex prussicus Szidat, 1937; Khawia prussica (Szidat, 1937) Markevich, 1951

This species was described as Bothrioscolex prussicus by Szidat (1937) from a single specimen found in the intestine of crucian carp, Carassius carassius, from Rossitten, Courland Spit (Kuhrische Nehrung), East Prussia (now the Russian enclave of Kaliningrad between Poland and Lithuania). The original description of $B$. prussicus was incomplete and only a very few measurements were provided, namely total length $(10 \mathrm{~mm})$, maximum width $(0.5 \mathrm{~mm})$ and the size of eggs $(51-53 \mu \mathrm{m} \times 33-35 \mu \mathrm{m})$; however, no true differential diagnosis of the new species was provided by Szidat (1937).

Scholz et al. (2011) considered K. prussica (Szidat, 1937) to be species incertae sedis, but they assumed that it may belong to Caryophyllaeus because it possesses a short uterine region and the preovarian vitelline follicles reaching almost to the ovarian arms. Assignment of B. prussicus to Caryophyllaeus is accepted in the present paper, but the species is considered to be species inquirenda because it differs from both Morphotype 3 of $C$. laticeps (see Han- zelová et al. 2015 for its morphology), and C. laticeps from Cyprinus carpio and Carassius carassius found in Italy (see Remarks on $C$. laticeps above) in the size of the cirrus-sac and posterior extent of the preovarian vitelline follicles, considering the original description by Szidat (1937) is correct and precise.

Caryophyllaeus truncatus von Siebold in Baird, 1853 and Caryophyllaeus tuba von Siebold in Baird, 1853 nomina nuda

A study of the original paper of von Siebold in Baird (1853) has revealed that the author named these two species found in Chondrostoma nasus and Salmo trutta fario Linnaeus, respectively, but did not provide their morphological description or other characterisation. Therefore, both taxa are nomina nuda according to the Article 12 of the International Code of Zoological Nomenclature (ICZN 1999).

\section{Caryophyllaeus minutus Chen, 1973}

This species was mentioned in Chen (1973) together with quite detailed line-drawing. However, the tapeworms identified as Caryophyllaeus minutus in fact represent another caryophyllidean species, the lytocestid Atractolytocestus huronensis, because they have identical shape of the body and scolex, extensive vitelline follicles uninterrupted alongside the ovarian lobes and the testes reaching posteriorly up to the ovary. Chen (1973) mentioned the date of the first description of C. minutus as 1964, but he in fact referred just to an unpublished manuscript of its description.

\section{Interrelationships of species of Caryophyllaeus based on molecular data}

Mitochondrial coxl and nuclear $l s r$ DNA sequences of numerous isolates of four of the seven species of the genus Caryophyllaeus are available. Concatenated dataset of both partial gene sequences analysed herein contained 2,029 alignable positions. Within the $630 \mathrm{bp}$ long cox 1 dataset $397(63 \%)$ characters were found variable and 349 $(88 \%)$ of them were parsimony-informative, whereas the $1,399 \mathrm{bp}$ long region of $l s r$ DNA offered only $426(30 \%)$ alignable positions, of which $256(60 \%)$ were parsimony-informative. Phylogenetic relationships within the genus Caryophyllaeus as well as its position within selected caryophyllidean genera are shown in Fig. 9.

The species of Caryophyllaeus form a statistically well-supported monophyletic group, which consists of two clades. The first clade comprises isolates of $C$. laticeps from different hosts including specimens from common carp in Italy, which form just weakly supported group. The position of Caryophyllaeus chondrostomi sp. n. within this clade is also uncertain, but this newly described species is distinct from all isolates of $C$. laticeps. The clade also includes isolates preliminary identified as $C$. laticeps morphotype 5 (see fig. 1 in Bazsalovicsová et al. 2014). These samples, designated as Caryophyllaeus sp. in the present study (Fig. 9), most probably represent separate species of Caryophyllaeus, which is pending formal description. The second group is formed by isolates of C. brachycollis and 


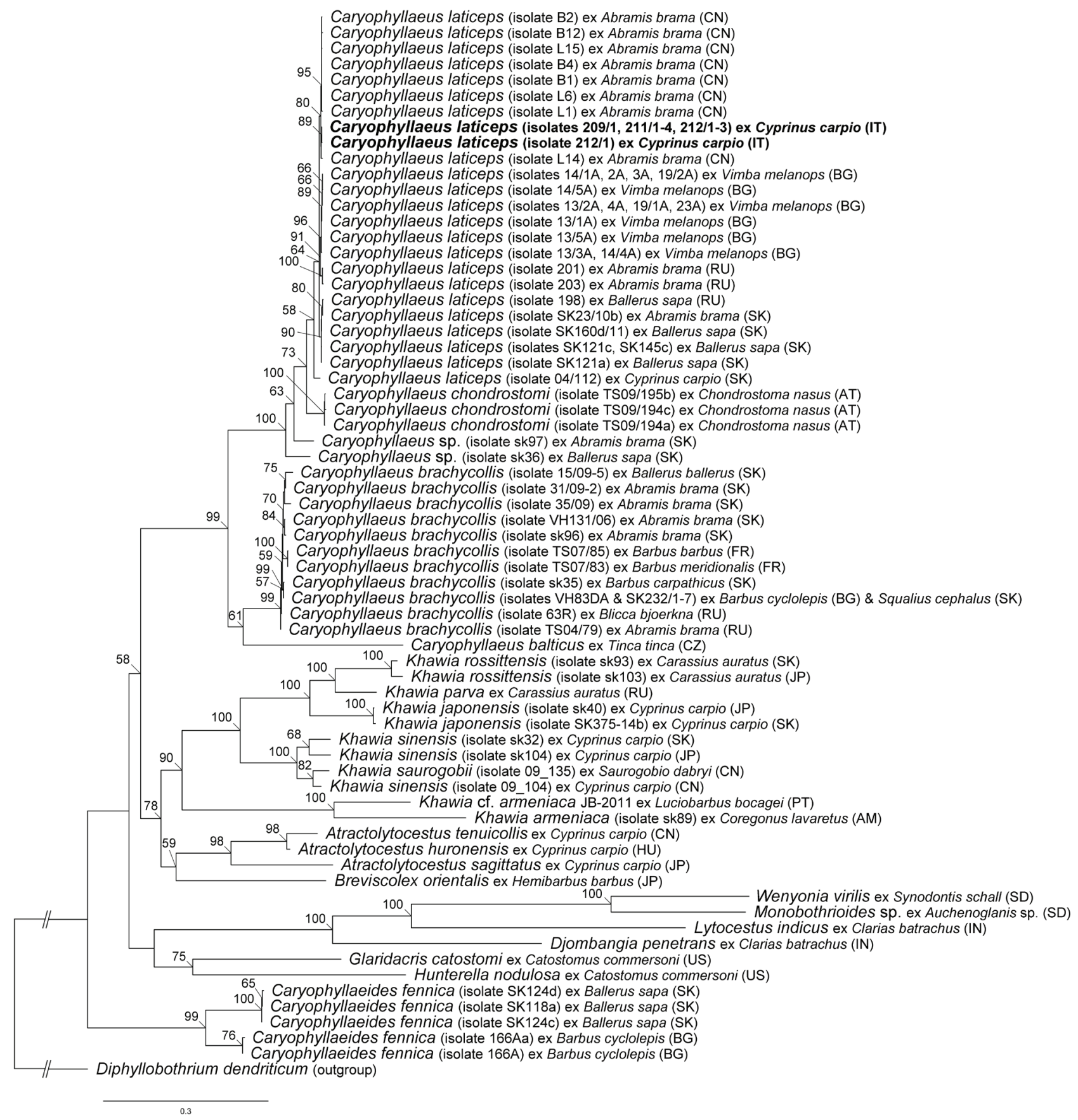

Fig. 9. Phylogenetic relationships of species of Caryophyllaeus Gmelin, 1790 and their position among the species of the Caryophyllidea evaluated by Maximum likelihood method based on concatenated dataset of two genes (coxl mtDNA and lsrDNA). Bootstrap supports for branch nodes estimated by RAxML and shown if exceed 55. The newly generated sequences are emboldened.

C. balticus, but sister-lineage relationship of the latter taxon with C. brachycollis is only weakly supported (Fig. 9).

\section{DISCUSSION}

\section{Taxonomic history and species composition of Caryophyllaeus}

The genus Caryophyllaeus was one of the species-richest genera of caryophyllidean cestodes (and in fact of all fish cestodes), with as many as 42 nominal species having been placed in the genus (Table 1). The number of species accommodated in this genus by different authors var- ied considerably, especially in the 20th century. Whereas Lühe (1910) included only Caryophyllaeus laticeps within the genus, Janiszewska (1954) mentioned only C. laticeps and $C$. brachycollis as valid species in Europe, and $\mathrm{Ku}-$ lakovskaya (1961) and Dubinina (1962) listed only three and four species, respectively, Hunter (1930), Wardle and McLeod (1952) and Yamaguti (1959) recognised as many as 13,14 and even 21 possibly valid species of Caryophyllaeus, respectively. However, the present authors consider the actual number of valid species of Caryophyllaeus to be much lower, with only seven species, including newly described C. chondrostomi, recognised as valid. The same 


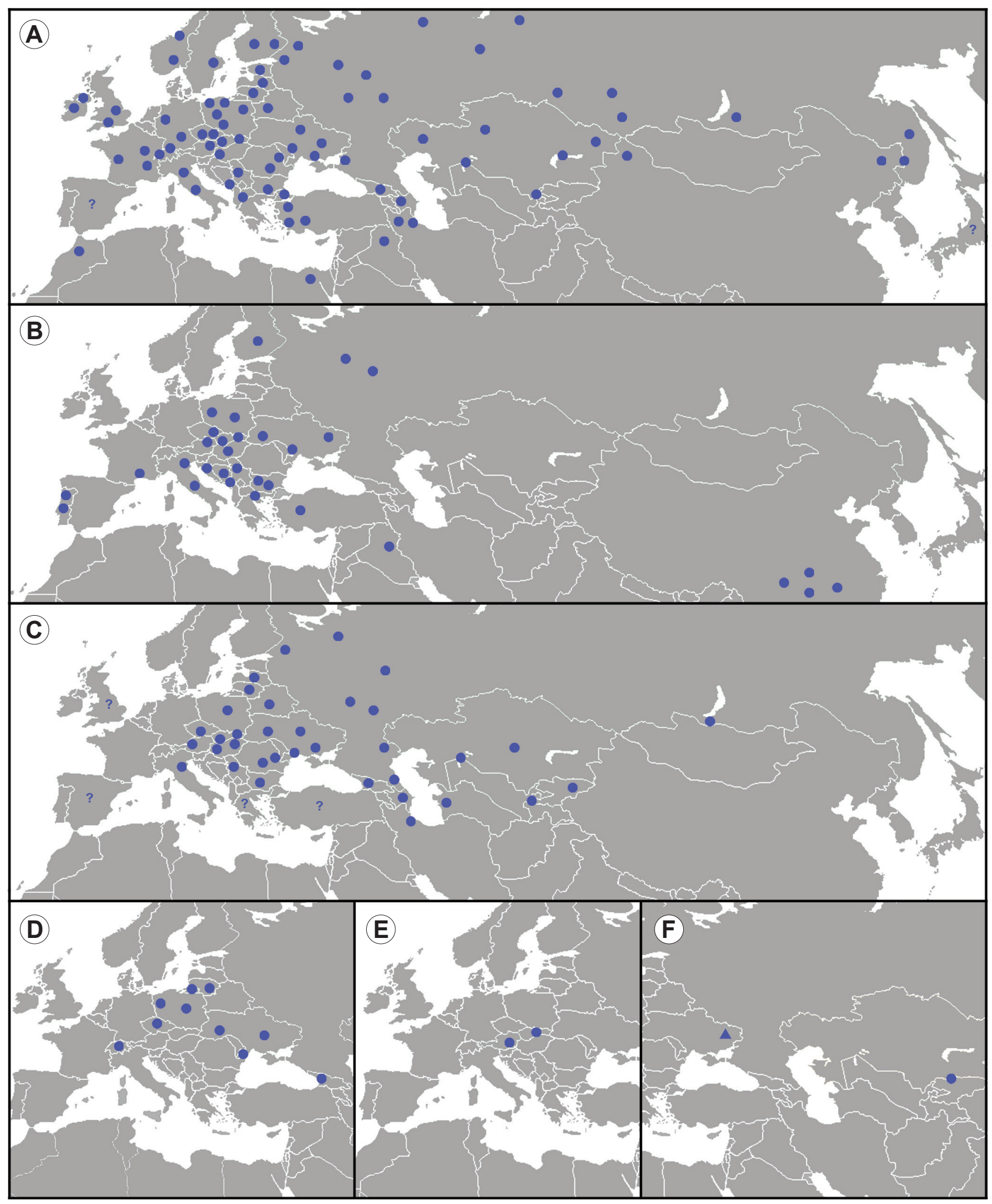

Fig. 10. Geographical distribution of species of Caryophyllaeus Gmelin, 1790 (blue dots in A-E). A - C. laticeps (Pallas, 1781); B - C. brachycollis Janiszewska, 1953; C - C. fimbriceps Annenkova-Chlopina, 1919; D - C. balticus (Szidat, 1941) comb. n.; $\mathbf{E}-$ C. chondrostomi sp. n.; F - C. auriculatus (Kulakovskaya, 1961) (blue triangle), C. syrdarjensis Skrjabin, 1913 (blue dot). Question marks indicate countries with reported occurrence, but exact locality is not known.

situation, i.e. considerable reduction of the number of valid species, was observed in other caryophyllidean genera, especially those in the Oriental and Ethiopian regions (Ash et al. 2011a,b, Schaeffner et al. 2011).
However, validity of some of the seven species listed above still requires confirmation. First, C. brachycollis resembles in the shape, size and structure of the cirrus-sac $C$. fimbriceps and both species may be conspecific. 
Second, the validity of $C$. auriculatus, which has never been found since its original description, also needs verification; it could be another morphotype of $C$. laticeps. Third, C. syrdarjensis from snowtrout (Barbinae) somewhat resembles Morphotype 1 of $C$. brachycollis, which is common in barbels (Barbinae), in the shape of the scolex and the anterior extent of the vitelline follicles and testes. Fourth, the taxonomic status of $C$. kashmirenses is unclear and its conspecificity with Adenoscolex oreini found in the same region (Kashmir) cannot be excluded. In contrast, the existence of more, yet undescribed species of Caryophyllaeus is probable as documented by the present description of a new species from common nase. Based on the data of Bazsalovicsová et al. (2014), cestodes from Ballerus sapa designated as Morphotype 5 also probably represent a new species, but their material is not sufficient for formal, good-quality description as a new species

\section{Morphotypes and diagnostic characters}

Recent morphological and molecular studies of C. brachycollis and $C$. laticeps have demonstrated the existence of several morphotypes, which differ from each other mainly in the scolex shape and the anterior extent of the testes and vitelline follicles (Barčák et al. 2014, Bazsalovicsová et al. 2014, Hanzelová et al. 2015). This observation challenges suitability of some of the previously used morphological diagnostic characteristics. In contrast, morphology of the terminal genitalia, especially the shape, size and structure of the cirrus-sac, appeared to be stable and thus suitable for differentiation of species of Caryophyllaeus (see Barčák et al. 2014, Hanzelová et al. 2015). In fact, it is sometimes difficult to interpret correctly morphological differences found in cestodes from different fish hosts: do they represent intraspecific variability of polymorphic cestodes with a wide range of definitive hosts such as $C$. laticeps or interspecific differences of separate species specific to their respective fish hosts, e.g. C. fimbriceps from common carp or C. auriculatus from Danilewski's dace? In such cases, molecular data may help unravel species boundaries between taxa from different hosts. The absence of molecular data on four species (C. auriculatus, C. fimbriceps, C. kashmirenses and $C$. syrdarjensis) impedes reliable assessment of their validity and interrelationships with congeneric taxa.

Assigning $C$. balticus with the exclusively cortical vitelline follicles (a feature typical for members of the Lytocestidae), to a genus of the Caryophyllaeidae, whose taxa are typified by the medullary vitelline follicles, challenges 'classical' classification of the caryophyllidean cestodes (Mackiewicz 1994). However, it has been demonstrated repeatedly over the last decade that the position of the inner longitudinal musculature in relation to the testes and vitelline follicles is a homoplastic character that may not reflect entirely the evolutionary history of these cestodes (Olson et al. 2008, Brabec et al. 2012, Scholz et al. 2015). The possession of paramuscular or even cortical position of vitelline follicles in the newly described species $C$. chondrostomi represents further evidence that the position of the vitelline follicles may vary even between congeneric species, which makes this taxonomic character problematic for family-level classification.

\section{Host associations}

No general pattern in host use by species of Caryophyllaeus seems to exist and fidelity of individual cestode species to their definitive hosts differs markedly from each other. Some species such as C. auriculatus, C. balticus, C. chondrostomi and C. syrdarjensis are oioxenous (infect only one host species), others ( $C$. fimbriceps) stenoxenous, i.e. infect a few related hosts, whereas the remaining species, i.e. C. laticeps and C. brachycollis, infect a wide spectrum of hosts of different subfamilies. However, it should be pointed out that the actual degree of host specificity is often biased by doubtful host records and/or incorrect identification. This is the main problem of faunal surveys, for which voucher specimens necessary for scrutiny are often not deposited. The absence of molecular data for specimens reported from atypical or uncommon hosts is another obstacle that impedes a more reliable assessment of host associations in Caryophyllaeus and other fish tapeworms (Scholz and Kuchta 2017).

\section{Importance of tapeworms of Caryophyllaeus}

Except for $C$. fimbriceps and $C$. laticeps, almost no data on the veterinary importance and pathology of species of Caryophyllaeus are available. Caryophyllaeus fimbriceps was considered a pathogenic parasite of cultured common carp (Bauer et al. 1973), but almost no records have been published since the 1970's. This cestode is now extremely rare or may even be extinct in most of its original distribution areas. The pathological impact of $C$. laticeps on wild cyprinid fishes was observed by Karanis and Taraschewski (1993), with the most pronounced pathological effects in freshwater bream; these included the chronic stage of infection, associated with formation of granulomas. Negative effect of $C$. laticeps on host intestinal microflora and physiology of digestion was reported by Izvekova et al. (1997, 2011) and Izvekova and Solovyev (2013).

Caryophyllaeus laticeps served as an important model for pioneer ecological studies including classical papers by Kennedy (1968, 1969), Kennedy and Walker (1969) and Anderson (1974a, 1976), which served as baselines for proposing basic rules of host-parasite relationships and epidemiology of parasite infections. Anderson (1974b) generated a stochastic model to describe one compartment of an indirect parasite life cycle, namely adult $C$. laticeps in the definitive host, cyprinid fishes in Europe. More recently, a few studies using $C$. laticeps as an indicator of ecosystem changes (Kurbanova et al. 2002) or colonisation and re-colonisation potential of some autogenic and allogenic parasite species (Kennedy 1998) have been published.

\section{Concluding remarks}

This synoptical review of the formally oldest genus of fish cestodes represents a follow-up of previous revisional studies focused on species-rich genera of the caryophyllidean cestodes such as Khawia, Paracaryophyllaeus 
Kulakovskaya, 1961 and Wenyonia Woodland, 1923, and on taxonomically complicated groups such as lytocestids from catfishes (Siluriformes) in the Oriental region (Ash et al. 2011a,b, Schaeffner et al. 2011, Scholz et al. 2011, 2014). Similarly as in some of these studies, an integrated approach has been applied, i.e. combination of morphological and molecular data, to critically review the species composition of the genus that housed as many as 42 nominal taxa over its long and convoluted taxonomic history. Interrelations of only four of the seven recognised species of Caryophyllaeus could be assessed using molecular data, but these data were crucial to unravel a high degree of morphological plasticity of the two most common species, namely $C$. brachycollis and $C$. laticeps, in which two and five morphotypes specific to different fish hosts were distinguished (Barčák et al. 2014, Bazsalovicsová et al. 2014, Hanzelová et al. 2015).

To facilitate identification of the species of Caryophyllaeus, a simple key based on morphological characteristics is provided. Nevertheless, species identity should be verified by comparing morphological and other information in diagnoses of individual species provided above and in the papers by Barčák et al. (2014) and Hanzelová et al. (2015).

\section{Key to the identification of species of Caryophyllaeus}

1 Cirrus-sac elongated, thick-walled without internal seminal vesicle (Fig. 5B) 2

- Cirrus-sac oval to subspherical, thin-walled, usually with internal seminal vesicle (Figs. 1B, 2E,F, 7C) ......... 3

2 Scolex spatulate or flabellate, without lobes and deep indentations, with tapered or curved anterior margin (Fig. $5 \mathrm{~A}, \mathrm{C}, 8 \mathrm{G}, \mathrm{H})$; in various cyprinids

C. brachycollis

- Scolex cuneicrispitate (Fig. 6A, 8F), i.e. flabellate with several short, but conspicuous indentations forming small lobes; in carp, Cyprinus carpio

C. fimbriceps

3 Uterine region represents $24-30 \%$ of testicular field; vitelline follicles present alongside ovary (Fig. 4B), cirrus-sac difficult to observe; in tench, Tinca tinca .......

C. balticus comb. n.

- Uterine region represents $7-25 \%$ of testicular field; vitelline follicles absent alongside ovary, cirrus-sac clearly visible

4 Scolex only slightly wider than neck (Figs. 3A, 6C, 8C); postovarian vitelline follicles small (Figs. 3B, 6D), few in number (16-28)

- Scolex significantly wider than neck (Figs. 1A, 7A,B, 8A,E); postovarian vitelline follicles large (Figs. 1B, 2B,D, 7C), usually numerous (more than 30 ) .. 6
5 Scolex with lateral ('auricular') projections (Figs. 3A, 8C); ovary at distance from posterior extremity; body slender; internal seminal vesicle absent (Fig. 3B); in Danilewski's dace, Leuciscus danilewskii

C. auriculatus

- Scolex without lateral ('auricular') projections (Fig. 6C); ovary close to posterior extremity; body robust; internal seminal vesicle present (Fig. 6D); in sattar snowtrout, Schizothorax curvifrons C. syrdarjensis

6 Body slender or moderately robust; anteriormost vitelline follicles in distance from anterior extremity (Figs. 1A, 2A,C), distance of anteriormost testes from anterior extremity represents $17-34 \%$ of total body length; in various cyprinids C. laticeps

- Body large, robust (Fig. 7A); distance of anteriormost vitelline follicles close to anterior extremity (Fig. 7A,B), distance of anteriormost testes from anterior extremity represents $4-14 \%$ of total body length; in common nase, Chondrostoma nasus

C. chondrostomi sp. n.

Acknowledgements. The authors are much obliged to two reviewers, including Andrea Waeschenbach, Natural History Museum, for valuable comments and helpful suggestions. The authors also express their gratitude to Bahram S. Dezfuli, University of Ferrara, Italy, for providing specimens from Carassius carassius; to Marialetizia Fioravanti, Monica Caffara, Andrea Gustinelli and Vasco Menconi, University of Bologna, Italy, for providing laboratory equipment and help with sampling and analyses; to Franz Jirsa, University of Vienna, Austria, and Anirban Ash, University of Burdwan, India, for help with examination of common nase in Austria; to Jan Brabec, Institute of Parasitology, BC CAS, České Budějovice, Czech Republic, for help with phylogenetic analyses; to Viera Kurimaiová, Institute of Parasitology, SAS, Košice, Slovakia, for help with the preparation of line drawings; to Andrea Vetešníková-Šimková, Masaryk University in Brno, Czech Republic, for kind providing specimens of $C$. brachycollis from Bosnia and Herzegovina, Croatia, and Portugal; to BingWen Xi, Chinese Academy of Fisheries Sciences, Wuxi, China, for information about C. minutus; and to curators and other staff of the following museums for making possible to study specimens of species of Caryophyllaeus: Sven Boström (SMNH), Alain de Chambrier and Jean Mariaux (MHNG-PLAT), Eileen Harris (BMNH), Oksana Greben (ZIK), Alex Galkin (ZIRAS), Kennet Lundin (GNHM), Birger Neuhaus (ZMB) and Helmut Sattmann (ZMW). This study was partially supported by the Slovak Research and Development Agency (projects APVV-065311), Grant Agency VEGA (project 2/0159/16), National Science Foundation, USA (PBI awards 0818696 and 0818823), Institute of Parasitology (RVO: 60077344) and Czech Science Foundation (project P505/12/G112 to T.S.). The study was undertaken within the framework of a project of the Research \& Development Operational Programme funded by the ERDF (code ITMS: 26220120022) (0.5). T.S. is obliged to Birger Neuhaus and Antje Schwiering from the Natural History Museum in Berlin for enabling access to old literature; his stay in Berlin was funded the EU SYNTHESYS project (DE-TAF-703 3080). 


\section{REFERENCES}

Anderson R.M. 1974a: Population dynamics of the cestode Caryophyllaeus laticeps (Pallas, 1781) in the bream (Abramis brama L.). J. Anim. Ecol. 43: 305-321.

ANDERSON R.M. 1974b: Mathematical models of host-helminth parasite interactions. In: M.B. Usher and M.H. Williamson (Eds.), Ecological Stability. Chapman and Hall, Ltd., London, pp. 43-69.

ANDERSON R.M. 1976: Seasonal variation in population dynamics of Caryophyllaeus laticeps. Parasitology 72: 281-305.

AnNenKova-Chlopina N.P. 1919: [Two new species of parasitic helminths of the genus Caryophyllaeus, found in the intestine of cyprinid fishes.] Izv. Ross. Akad. Nauk, Serie VI, 12: 97-110. (In Russian.)

Ash A., Scholz T., Oros M., Kar P.K. 2011a: Tapeworms (Cestoda: Caryophyllidea), parasites of Clarias batrachus (Pisces: Siluriformes) in the Indomalayan Region. J. Parasitol. 97: 435-459.

Ash A., Scholz T., Oros M., Levron C., Kar P.K. 2011b: Cestodes (Caryophyllidea) of the stinging catfish Heteropneustes fossilis (Siluriformes: Heteropneustidae) from Asia. J. Parasitol. 97: 899-907.

BAIRD W. 1853: Catalogue of the Species of Entozoa, or Intestinal Worms, Contained in the Collection of the British Museum. Woodfall and Kinder, London, $132 \mathrm{pp}$.

Barčák D., Oros M., Hanzelová V., Scholz T. 2014: Phenotypic plasticity in Caryophyllaeus brachycollis Janiszewska, 1953 (Cestoda: Caryophyllidea): does fish host play a role? Syst. Parasitol. 88: 153-166.

Bauer O.N., Musselius V.A., Strelkov Y.A. 1973: Diseases of Pond Fishes. Israel Program for Scientific Translations, Jerusalem, $220 \mathrm{pp}$.

Bazitov A.A. 1979: [Spermatogenesis in Caryophyllaeus fimbriceps and Khawia sinensis (Caryophyllidea).] Mat. Nauchn. Konf. Vsesoyuz. Obshch. Gelmintol. 31: 3-9. (In Russian.)

Bazsalovicsová E., Králová-Hromadová I., Brabec J., HaNzelová V., Oros M., Scholz T. 2014: Conflict between morphology and molecular data: a case of the genus Caryophyllaeus (Cestoda, Caryophyllidea), monozoic tapeworm of cyprinid fishes. Folia Parasitol. 61: 346-352.

Bazsalovicsová E., Králová-Hromadová I., Štefka J., Scholz T., Hanzelová V., Vávrová S., Szemes T., Kirk R. 2011: Population study of Atractolytocestus huronensis (Cestoda: Caryophyllidea), an invasive parasite of common carp introduced to Europe: mitochondrial cox 1 haplotypes and intragenomic ribosomal ITS2 variants. Parasitol. Res. 109: 125-131.

BÉGUIN F. 1966: Etude au microscope électronique de la cuticle et de ses structures associées chez quelques cestodes. Essai d'histologie comparée. Z. Zellforsch. 72: 30-46.

van Beneden P.J. 1858: Mémoire sur les Vers Intestinaux. C. R. Sci. Soc. Biol., Paris 2: 376 pp.

Biserova N.M., Kuryrev I.A., Jensen K. 2014: GABA in the nervous system of the cestodes Diphyllobothrium dendriticum (Diphyllobothriidea) and Caryophyllaeus laticeps (Caryophyllidea), with comparative analysis of muscle innervation. J. Parasitol. 100: 411-421.

BLOCH M.E. 1782: Abhandlung von der Erzeugung der Eingeweidewürmer und den Mitteln wieder dieselben: eine von der Königlich Dänischen Societät der Wissenschaften zu Copenhagen gekrönte Preisschrift. S. F. Hesse, Berlin, 54 pp.

Brabec J., Scholz T., Králová-Hromadová I., BazsalovICSOVÁ E., Olson P.D. 2012: Substitution saturation and nuclear paralogs of commonly employed phylogenetic markers in the Caryophyllidea, an unusual group of non-segmented tapeworms (Platyhelminthes). Int. J. Parasitol. 42: 259-267.

Bruñanská M., Drobníková P., Mackiewicz J.S., NebesáŘová J. 2013: Reinvestigation of vitellogenesis in Caryophyllaeus laticeps (Pallas, 1781) (Cestoda, Caryophyllidea, Caryophyllaei- dae), monozoic tapeworm of Abramis brama (Pisces, Teleostei). Helminthologia 50: 73-81.

BRUŇANSKÁ M., Kostič B. 2012: Revisiting caryophyllidean type of spermiogenesis in the Eucestoda based on spermatozoon differentiation and ultrastructure of Caryophyllaeus laticeps (Pallas, 1781). Parasitol. Res. 110: 141-149.

Calentine R.L., Ulmer M.J. 1961: Khawia iowensis n. sp. (Cestoda: Caryophyllaeidae) from Cyprinus carpio L. in Iowa. J. Parasitol. 47: 795-805.

Chen C.L. 1973: [An Illustrated Guide to the Fish Diseases and Causative Pathogenic Fauna and Flora in Hubei Province.] Science Press, Beijing, 271 pp. (In Chinese.)

Chervy L. 2002: The terminology of larval cestodes or metacestodes. Syst. Parasitol. 52: 1-33.

Chervy L. 2009: Unified terminology for cestode microtriches: a proposal from the International Workshops on Cestode Systematics in 2002-2008. Folia Parasitol. 56: 199-230.

Chubi J.C. 1982: Seasonal occurrence of helminths in freshwater fishes. Part IV. Adult Cestoda, Nematoda and Acanthocephala. Adv. Parasitol. 20: 1-292.

Davydov V.G., Poddubnaya L.G. 1988: [Functional morphology of frontal and uterine glands in cestodes of the order Caryophyllidea.] Parazitologiya 22: 449-457. (In Russian.)

Davydov V.G., Poddubnaya L.G., Kolesnikova G.A. 1994: [Ultrastructure of genital system ducts of Caryophyllaeus laticeps (Cestoda, Caryophyllidea).] Parazitologiya 28: 501-509. (In Russian.)

Demshin N.I. 1984: [Biology of Caryophyllaeus fimbriceps Annenkova-Chlopina, 1919 and Khawia parva (Zmejev, 1936) (Caryophyllidea, Cestoda) - parasites of cyprinid fish.] Parazity Zhivotnykh i Rastenii, AN SSSR: 63-70. (In Russian.)

Dikanović V., SKorić S., CAKIĆ P. 2013: Representatives of tapeworms (Cestoda) of fishes in Belgrade section of the Danube river. In: V. Poleksić (Ed.), VI Int. Conf. Water \& Fish. Faculty of Agriculture, University of Belgrade, Belgrade. Abstracts of papers, pp. 402-408.

Dogiel V.A., Вукноvsкy B.E. 1939: [Parasites of the Caspian Sea Fishes.] Academy of Sciences of the USSR, Moscow - Leningrad, $151 \mathrm{pp}$. (In Russian.)

Dubinina M.N. 1962: [Class tapeworms Cestoidea Rud., 1801.] In: B.E. Bykhovskii (Ed.), Key to the Parasites of Freshwater Fish of the USSR. Izd. Akad. Nauk. USSR, Moscow - Leningrad, pp. 384-438. (In Russian.)

Dubinina M.N. 1987: [Class Tapeworms - Cestoda Rudolphi, 1808.] In: O.N. Bauer (Ed.), Key to the Parasites of Freshwater Fishes of the USSR. Nauka, Leningrad, pp. 5-76. (In Russian.)

Evlanov I.A., KoloKolnikova S.E. 1991: [Population ecology of the cestode Caryophyllaeus laticeps (Cestoda, Caryophyllidae) in the bream population.] Zool. Zh. 70: 12-16. (In Russian.)

Evlanov I.A., Kolokolnikova S.E., Kozlovsky S.V. 1992: [Population genetic interrelations in the bream Caryophyllaeus laticeps (Cestoda) system.] Parazitologiya 26: 240-245. (In Russian.)

Fotedar D.N. 1958: On a new caryophyllaeid cestode, Adenoscolex oreini gen. et sp. nov. from fresh-water in Kashmir, and a note on some related genera. J. Helminthol. 32: 11-16.

Froese R., Pauly D. 2016: Fishbase. World Wide Web electronic publication. www.fishbase.org, 10/2016

Fuhrmann O., Baer J.G. 1925: Zoological results of the third Tanganyika expedition conducted by Dr. W.A. Cunnington, 1904-1905. Report on the Cestoda. Proc. Zool. Soc. London 1925 (No. VI): 79-100.

GeOrgescu R., Naziru M. 1984: [Health status of fish population in lakes near the capital.] Bul. Cercetari Piscicole, Dimbovita 4: 91-98. (In Romanian, with English summary.)

Gibson D.I. 2013a: Fauna Europaea: Caryophyllidea, Caryophyllaeus laticeps. Fauna Europaea version 2.6.2, www.faunaeur. org. 
Gibson D.I. 2013b: Fauna Europaea: Caryophyllidea, Khawia baltica. Fauna Europaea version 2.6.2, www.faunaeur.org.

Gibson D.I. 2013c: Fauna Europaea: Caryophyllidea, Caryophyllaeus brachycollis. Fauna Europaea version 2.6.2, www.faunaeur.org.

Gibson D.I. 2013d: Fauna Europaea: Caryophyllidea, Caryophyllaeus fimbriceps. Fauna Europaea version 2.6.2, www.faunaeur. org.

Gibson D.I., Bray R.A., HARris E.A. (Compilers) 2005: Host-Parasite Database of the Natural History Museum, London. www.nhm.ac.uk.

Gmelin J.F. 1790: Caroli a Linné, Systema Naturae. Tom. I. Pars VI. Beer, Lipsiae, pp. 3021-3910.

Goeze J.A.E. 1782: Versuch einer Naturgeschichte der Eingeweidewürmer thierischer Körper. Ph.U. Pape, Blankenburg, 472 pp.

Hanzelová V., Oros M., BarčáK D., Miklisová D., Kirin D., Scholz T. 2015: Morphological polymorphism in tapeworms: redescription of Caryophyllaeus laticeps (Pallas, 1781) (Cestoda: Caryophyllidea) and characterisation of its morphotypes from different fish hosts. Syst. Parasitol. 90: 177-190.

Hunter G.W. III. 1927: Notes on the Caryophyllaeidae of North America. J. Parasitol. 14: 16-26.

Hunter G.W. III. 1930: Studies on the Caryophyllaeidae of North America. Illinois Biol. Monogr. 11 (1927), 186 pp.

ICZN 1999: International Code of Zoological Nomenclature, Fourth Edition. The International Trust for Zoological Nomenclature, London, $306 \mathrm{pp}$.

Izvekova G.I., Kuperman B.I., Kuzmina V.V. 1997: Digestion and digestive-transport surfaces in cestodes and their fish hosts. Comp. Biochem. and Physiol. 118A: 1165-1171.

Izvekova G.I., Solovyev M.M. 2013: Activity of digestive hydrolases in fish infected with cestodes. Biol. Bull. Rev. 3: 167-175.

Izvekova G.I., Solovyev M.M., Izvekov E.I. 2011: Effect of Caryophyllaeus laticeps (Cestoda, Caryophyllidea) upon activity of digestive enzymes in bream. Biol. Bull. 2011: 50-56.

JANISZEWSKA J. 1953: Caryophyllaeus brachycollis n. sp. from ciprinoid [sic!] fishes. Zool. Pol. 6: 57-68.

JANISZEWSKA J. 1954: [Caryophyllaeidae of Europe with focus on Poland.] Prace Wroclawskiego Towarzystva Naukowego, Seria B, 66, 74 pp. (In Polish.)

Joyeux C., Baer J.G. 1936: Faune de France, 30. Cestodes. Lechevalier et Fils, Paris, 613 pp

Karanis P., TaraschewsKi H. 1993: Host parasite interface of Caryophyllaeus laticeps (Eucestoda, Caryophyllidae) in three species of fish. J. Fish Dis. 16: 371-379.

Katoh K., Standley D.M. 2013: MAFFT multiple sequence alignment software version 7: improvements in performance and usability. Mol. Biol. Evol. 30: 772-780.

Kearse M., Moir R., Wilson A., Stones-Havas S., Cheung M., Sturrock S., Buxton S., Cooper A., Markowitz S., Duran C., Thierer T., Ashton B., Mentjies P., DrumMOND A. 2012: Geneious Basic: an integrated and extendable desktop software platform for the organization and analysis of sequence data. Bioinformatics 28: 1647-1649.

KenNEDy C.R. 1968: Population biology of the cestode Caryophyllaeus laticeps (Pallas, 1781) in dace, Leuciscus leuciscus L., of the River Avon. J. Parasitol. 54: 538-543.

Kennedy C.R. 1969: Seasonal incidence and development of the cestode Caryophyllaeus laticeps (Pallas) in the River Avon. Parasitology 59: 783-794.

Kennedy C.R. 1994: The ecology of introductions. In: A.W. Pike and J.W. Lewis (Eds.), Parasitic Diseases of Fish. Samara Publishing Limited, Tresaith, pp. 189-209.

KENNEDY C.R. 1998: Aquatic birds as agents of parasite dispersal: a field test of the effectiveness of helminth colonisation strategies. Bull. Scand. Soc. Parasitol. 8: 23-28.

Kennedy C.R., Walker P.J. 1969: Evidence for an immune response by dace, Leuciscus leuciscus, to infections by the cestode Caryophyllaeus laticeps. J. Parasitol. 55: 579-582.
Khara H., Sattari M., Nezami S. 2011: Parasites of some bony fishes in Boojagh wetland from the southwest of the Caspian Sea. Caspian J. Environ. Sci. 9: 37-46.

KöRTING W. 1975: Larval development of Bothriocephalus sp. (Cestoda: Pseudophyllidea) from carp (Cyprinus carpio L.) in Germany. J. Fish Biol. 7: 727-733.

Králová-Hromadová I., Bazsalovicsová E., Bokorová V., Hanzelová V. 2013: Ribosomal ITS2 structure in Caryophyllaeus laticeps and Caryophyllaeus brachycollis (Cestoda: Caryophyllidea), parasites of cyprinid fish. Helminthologia 50: 235-237.

Králová-Hromadová I., Bazsalovicsová E., Oros M., Scholz T. 2012: Sequence structure and intragenomic variability of ribosomal ITS2 in monozoic tapeworms of the genus Khawia (Cestoda: Caryophyllidea), parasites of cyprinid fish. Parasitol. Res. 111: 1621-1627.

Králová-Hromadová I., Minárik G., Bazsalovicsová E., Mikulíček P., Oravcová A., Pálková L., Hanzelová V. 2015: Development of microsatellite markers in Caryophyllaeus laticeps (Cestoda: Caryophyllidea), monozoic fish tapeworm, using next-generation sequencing approach. Parasitol. Res. 114: 721-726.

Kulakovskaya O.P. 1961: [On the fauna of the Caryophyllaeidae (Cestoda, Pseudophyllidea) of the USSR.] Parazitol. Sb. 20: 339354. (In Russian.)

Kulakovskaya O.P. 1962: [Development of Caryophyllaeidae (Cestoda) in an intermediate host.] Zool. Zh. 41: 986-992. (In Russian, with English summary.)

Kulakovskaya O.P. 1969: [Cestodes of freshwater fish of the Ukrainian SSR.] Summary (Avtoreferat) of D.Sc. thesis. Academy of Sciences of the Ukrainian SSR, Kiev, 45 pp. (In Ukrainian.)

Kulakovskaya O.P., Svirepo B.G. 1967: [Alteration of some blood indices of carp and sazan-carp hybrids on infection with Caryophyllaeidae.] Vest. Zool. 6: 38-42. (In Russian.)

KUlmatyCKi W.J. 1928: Caryophyllaeus niloticus nov. sp. In: S. Jägerskiöld (Ed.), Results of the Swedish Zoological Expedition to Egypt and the White Nile 1901. Uppsala, pp. 1-19.

Kurbanova A.I., UraZbaev A.N., Yusupov O.Y. 2002: [Changes in parasite fauna of certain fish species in the southern Aral Sea under anthropogenic pressure.] Vestn. Zool. 36: 29-34. (In Russian.)

Lanfear R., Calcott B., Ho S.Y., Guindon S. 2012: PartitionFinder: combined selection of partitioning schemes and substitution models for phylogenetic analyses. Mol. Biol. Evol. 29: 1695-1701.

Littlewood D.T.J., Curini-Galletti M., Herniou E.A. 2000: The interrelationships of Proseriata (Platyhelminthes: Seriata) flatworms tested with molecules and morphology. Mol. Phylogenet. Evol. 16: 449-466.

LitTlewood D.T.J., Olson P.D. 2001: Small subunit rDNA and the Platyhelminthes: signal, noise, conflict and compromise. In: D.T.J. Littlewood and R.A. Bray (Eds.), Interrelationships of the Platyhelminthes. Taylor \& Francis, London, pp. 262-278.

Lockyer A.E., Olson P.D., Littlewood D.T.J. 2003: Utility of complete large and small subunit rRNA genes in resolving the phylogeny of the Neodermata (Platyhelminthes): implications and a review of the cercomer theory. Biol. J. Linn. Soc. 78: $155-171$.

LüHE M. 1910: Die Süsswasserfauna Deutschlands. Parasitische Plattwürmer. II. Cestodes. Gustav Fischer Verlag, Jena, 153 pp.

MaCKIEwicz J.S. 1962: Systematic position of Caryophyllaeus fuhrmanni Szidat, 1937 and Lytocestus alestesi Lynsdale, 1956 (Cestoidea: Caryophyllidea). Rev. Suisse Zool. 69: 729-735.

MACKIEWICZ J.S. 1968: Vitellogenesis and eggshell formation in Caryophyllaeus laticeps (Pallas) and Caryophyllaeides fennica (Schneider) (Cestoidea: Caryophyllaeidea). Z. Parasitenkd. 30: $18-32$.

MACKIEWICZ J.S. 1972: Caryophyllidea (Cestoidea): a review. Exp. Parasitol. 31: 417-512. 
Mackiewicz J.S. 1974: The genus Caryophyllaeus Gmelin (Cestoidea: Caryophyllidea) in the Nearctic. Proc. Helminthol. Soc. Wash. 41: 184-191.

Mackiewicz J.S. 1994: Order Caryophyllidea van Beneden in Carus, 1863. In: L.F. Khalil, A. Jones and R.A. Bray (Eds.), Keys to the Cestode Parasites of Vertebrates. CAB International, Wallingford, pp. 21-43.

MARIAUX J. 1998: A molecular phylogeny of the Eucestoda. J. Parasitol. 84: 114-124.

Mehra H.R. 1930: On a new species of Caryophyllaeus O. F. Müller from Kashmir with remarks on Lytocestus indicus (Moghe) 1925. Proc. 17th Ind. Sci. Congress, pp. 247.

Milbrink G. 1975: Population biology of the cestode Caryophyllaeus laticeps (Pallas) in bream, Abramis brama (L.), and the feeding of fish on oligochaetes. Rep. Inst. Freshw. Res., Drottningholm, Lund 54: 36-51.

Mitterpák J., HuŇady J. 1984: [Economic importance of Caryophyllaeus fimbriceps in carp]. Veterinářství 34: 125. (In Slovak.)

MrázeK A. 1901: [Ueber die Larve von Caryophyllaeus mutabilis Rud.] Cbl. Bakteriol., Parasitenkd. Infektionskrankh. 29: 485-491.

MÜLLER O.F. 1787: Verzeichniss der bisher entdeckten Eingeweidewürmer, der Thiere, in welchen sie gefunden worden, und der besten Schriften, die derselben erwähnen. Naturforscher 22: 33-86.

Musselius V., Ivanova N., Laptev V., Apazidi L. 1964: [Khawia sinensis Hsü, 1935 of carp.] Ribov. Ribolovstvo 3: 25-27. (In Russian.)

Nybelin O. 1922: Anatomisch-systematische Studien über Pseudophyllideen. Göteborgs Kungl. Vet. Vitt.-Samh. Handl. 26: $1-228$.

Olson P.D., Cribi T.H., Tkach V.V., Bray R.A., Littlewood D.T.J. 2003: Phylogeny and classification of the Digenea (Platyhelminthes: Trematoda). Int. J. Parasitol. 33: 733-755.

Olson P.D., Littlewood D.T.J., Bray R.A., Mariaux J. 2001: Interrelationships and evolution of the tapeworms (Platyhelminthes: Cestoda). Mol. Phylogenet. Evol. 19: 443-467.

Olson P.D., Poddubnaya L.G., Littlewood D.T.J., Scholz T. 2008: On the position of Archigetes and its bearing on the early evolution of the tapeworms. J. Parasitol. 94: 898-904.

Oros M., Hanzelová V., Scholz T. 2004: The cestode Atractolytocestus huronensis (Caryophyllidea) continues to spread in Europe: new data on the helminth parasite of the common carp. Dis. Aquat. Organ. 62: 115-119.

Oros M., Hanzelová V., Scholz T. 2009: Tapeworm Khawia sinensis: review of the introduction and subsequent decline of a pathogen of carp, Cyprinus carpio. Vet. Parasitol. 164: 217222.

Oros M., Hanzelová V., Scholz T., Mackiewicz J.S. 2008: Phylogenetic relationships of the monozoic tapeworms (Eucestoda: Caryophyllidea) inferred from morphological characters. Syst. Parasitol. 70: 1-14.

Oros M., Scholz T., Hanzelová V., Mackiewicz J.S. 2010: Scolex morphology of monozoic cestodes (Caryophyllidea) from the Palaearctic Region: a useful tool for species identification. Folia Parasitol. 57: 37-46.

Pallas P.S. 1781: Bemerkungen über die Bandwürmer in Menschen und Tieren. Neu Nordische Beytrage zur physikalischen und geographischen Erd- und Völker Beschreibung, Naturgeschichte und Ökonomie. Erster Band. J.Z. Logan, St. Peterburg and Leipzig, pp. 39-112.

Pleijel F., Jondelius U., Norlinder E., Nygren A., Oxelman B., Schander C., Sundberg P., Thollesson M. 2008: Phylogenies without roots? A plea for the use of vouchers in molecular phylogenetic studies. Mol. Phyl. Evol. 48: 369-371.

Poddubnaya L.G. 1995: [Peculiarities of the integument genesis in procercoids of caryophyllidean cestodes.] Parazitologiya 29: 13-18. (In Russian.)

Poddubnaya L.G. 1996: [A development of microtriches in caryophylloid cestodes.] Parazitologiya 30: 126-131. (In Russian.)
Protasova E., Kuperman B., Roytman V., Poddubnaya L. 1990: [Caryophyllidea of the fauna of the USSR.] Nauka, Moscow, 238 pp. (In Russian.)

Rahemo Z.I.F., Mohammad S.A. 2004: Four species of monozoic cestodes from the intestine of cyprinid fishes in Iraq. Dirasat Med. Biol. Sci. 31: 149-155.

REDA E.S.A. 1988: An analysis of parasite fauna of bream, Abramis brama (L.), in Vistula near Warszawa in relation to the character of fish habitat. I. Review of parasite species. Acta Parasitol. Pol. 32: 309-326.

Rehder D.D. 1959: Some aspects of the life of the carp, Cyprinus carpio in the Des Moines River, Boone County, Iowa. Iowa State J. Sci. 34: 11-26.

Richards K.S., Arme C. 1982a: Sensory receptors in the scolexneck region of Caryophyllaeus laticeps (Caryophyllidea: Cestoda). J. Parasitol. 68: 416-423.

Richards K.S., Arme C. 1982b: The microarchitecture of the structured bodies in the tegument of Caryophyllaeus laticeps (Caryophyllidea: Cestoda). J. Parasitol. 68: 425-432.

Sattari M., Mokhayer B., Khara H., Nezami S., Shafit S. 2007: Occurrence and intensity of parasites in some bonyfish species of Anzali wetland from the southwest of the Caspian Sea. Bull. Eur. Assoc. Fish Pathol. 27: 54-60.

Schaeffner B.C., JiRKŮ M., Mahmoud Z.N., Scholz T. 2011: Revision of Wenyonia Woodland, 1923 (Cestoda: Caryophyllidea) from catfishes (Siluriformes) in Africa. Syst. Parasitol. 79: 83-107.

SCHмIDT G.D. 1986: CRC Handbook of Tapeworm Identification. CRC Press, Boca Raton, Florida, 675 pp.

SCHOLZ T. 1987: First record of the cestode Monobothrium wageneri Nybelin, 1922 (Caryophyllidea) in Czechoslovakia. Folia Parasitol. 34: 128-130.

Scholz T. 1989: Amphilinida and Cestoda, Parasites of Fish in Czechoslovakia. Academia, Praha, 56 pp.

Scholz T. 1993: On the development of Khawia baltica Szidat, 1942 (Cestoda, Lytocestidae), a parasite of tench, Tinca tinca (L). Folia Parasitol. 40: 99-103.

Scholz T., Brabec J., Králová-Hromadová I., Oros M., Bazsalovicsová E., Ermolenko A., Hanzelová V. 2011: Revision of Khawia spp. (Cestoda: Caryophyllidea), parasites of cyprinid fish, including a key to their identification and molecular phylogeny. Folia Parasitol. 58: 197-223.

Scholz T., Kuchta R. 2017: A digest of bony fish tapeworms. Vie milieu - Life Environm. 67 (in press).

Scholz T., Kuchta R., Williams C. 2012: Bothriocephalus acheilognathi. In: P.T.K. Woo and K. Buchmann (Eds.), Fish Parasites. Pathobiology and Protection. Chapter 18. CAB International, Wallingford, pp. 282-297.

Scholz T., Oros M. 2017: Caryophyllidea van Beneden in Carus, 1863. In: J.N. Caira and K. Jensen (Eds.), Planetary Biodiversity Inventory (2008-2017): Tapeworms from Vertebrate Bowels of the Earth. University of Kansas, Natural History Museum, Special Publication No. 25, Lawrence, pp. 47-64.

Scholz T., Oros M., Bazsalovicsová E., Brabec J., Waeschenbach A., Xi B.W., Aydoğdu A., BesprozvannyKh V., Shimazu T., Králová-Hromadová I., Littlewood D.T.J. 2014: Molecular evidence of cryptic diversity in Paracaryophyllaeus (Cestoda: Caryophyllidea), parasites of loaches (Cobitidae) in Eurasia, including description of $P$. vladkae n. sp. Parasitol. Int. 63: 841-850.

Scholz T., Oros M., Choudhury A., Brabec J., WaeschenBACH A. 2015: New circumscription of freshwater fish parasites Monobothrium Diesing, 1863 and Promonobothrium Mackiewicz, 1968 (Cestoda: Caryophyllidea) using morphological and molecular evidence. J. Parasitol. 101: 29-36.

SCHRANK F.P. 1788: Verzeichniss der bisher hinlänglich bekannten Eingeweidewürmer, nebst einer Abhandlung über ihre Anverwandschaften. Johann Baptist Strobl, München, 116 pp. 
Sekutowicz S.T. 1934: Untersuchungen zur Entwicklung and Biologie von Caryophyllaeus laticeps (Pall.).] Mem. Acad. Pol. Sci. Lettres, Series B, Sci. Nat. 6: 11-26.

SkrJabin K.I. 1913: Fischparasiten aus Turkestan, I. Hirudinea et Cestodaria. Arch. Naturgesch., Abt. A 79: 1-10.

ŠrÁmeK A. 1901: Helminthen der an der zoologischen Station in Podiebrad (Böhmen) untersuchten Fische. Arch. Naturwissenschaft. Landesdurchforsch. Böhmen 11: 94-118.

Stamatakis A. 2006: RAxML-VI-HPC: Maximum likelihood-based phylogenetic analyses with thousands of taxa and mixed models. Bioinformatics 22: 2688-2690.

Stiles C.W., Hassal A. 1912: Index-Catalogue of Medical and Veterinary Zoology. Publication of the U.S., Health Amid Marine-Hospital Service, Washington, $467 \mathrm{pp}$.

SzIDAT L. 1937: Über einige neue Caryophyllaeiden aus ostpreussischen Fischen. Z. Parasitenkd. 9: 771-786.

SzIDAT L. 1941: Über die Caryophyllaeiden-Gattung Khawia H. F. Hsü 1935 und eine neue Art dieser Gattung, Khawia baltica n. spec. Z. Parasitenkd. 12: 120-132.

Tiмм T. 1972: On the reproduction of Euilyodrilus bedoti (Piquet, 1913) (Oligochaeta, Tubificidae). Eesti NSV Teaduste Akadeemia Toimetised Biologia 21: 235-241. (Cited from Milbrink 1975.)

VASILEVSKAYA L.K. 1984: [Formation of the caryophyllid fauna of fish in the Pechenezhskii reservoir.] Vestn. Kharskovsk. Univ. 262: 82-83. (In Russian.)

Received 8 February 2017

Accepted 18 June 2017
Waeschenbach A., Webster B.L., Littlewood D.T.J. 2012: Adding resolution to ordinal level relationships of tapeworms (Platyhelminthes: Cestoda) with large fragments of mtDNA. Mol. Phylogenet. Evol. 63: 834-847.

Wardle R.A., McLeod J.A. 1952: The Zoology of Tapeworms. University of Minnesota Press, Minneapolis, $780 \mathrm{pp}$.

Werle E., Schneider C., Renner M., Volker M., Fiehn W. 1994: Convenient singlestep, one tube purification of PCR products for direct sequencing. Nucl. Acids Res. 22: 4354-4355.

WoOdLAnd W.N.F. 1923: On some remarkable new forms of Caryophyllaeidae from Anglo-Egyptian Sudan, and a revision of the families of the Cestodaria. Q. J. Microsc. Sci. 67: 435-472

Xi B.W., Barčák D., Oros M., Chen K., Xie J. 2016: The occurrence of the common European fish cestode Caryophyllaeus laticeps (Pallas, 1781) in the River Irtysh, China: a morphological characterization and molecular data. Acta Parasitol. 61: 493-499.

Xi B.W., Oros M., Wang G.T., Scholz T., Xie J. 2013: Khawia abbottinae sp. n. (Cestoda: Caryophyllidea) from the Chinese false gudgeon Abbottina rivularis (Cyprinidae: Gobioninae) in China: morphological and molecular data. Folia Parasitol. 60: $141-148$.

Yamaguti S. 1959: Systema Helminthum, vol. II. The Cestodes of Vertebrates. Keigaku Publishing House, Tokyo, 860 pp.

Cite this article as: Barčák D., Oros M., Hanzelová V., Scholz T. 2017: A synoptic review of Caryophyllaeus Gmelin, 1790 (Cestoda: Caryophyllidea), parasites of cyprinid fishes. Folia Parasitol. 64: 027. 